\title{
Exploring the niche of a highly effective biocalcifier: calcification of the eukaryotic microalga Oocardium stratum Nägeli 1849 in a spring stream of the Eastern Alps
}

\author{
Ha $\operatorname{Tran}^{1,3} \cdot$ Eugen $\operatorname{Rott}^{2} \cdot$ Diethard Sanders $^{1}$ (D) \\ Received: 30 October 2018 / Accepted: 23 May 2019 / Published online: 19 June 2019 \\ (c) The Author(s) 2019
}

\begin{abstract}
Microbially mediated calcification is a major process of carbonate production, yet little is known about eukaryotic microalgal calcifiers. We describe calcification and propagation of the unicellular microalga Oocardium stratum in an Alpine spring stream. The spring sheds $\mathrm{Ca}-\mathrm{Mg}-\mathrm{HCO}_{3}$ water with a temperature of $8-11{ }^{\circ} \mathrm{C}$. The biota is dominated by $O$. stratum and diatoms; mosses, cyanobacteria, and filamentous eukaryotic algae are accessories. $O$. stratum colonize various substrates within the stream throughout the year. When colonizing, single cells attached to mucilage, then induced precipitation of a rim of calcite, and underwent a first division. A mature clone of $O$. stratum typically consists of single cells each housed within a calcite tube precipitated by the microalga. Upon cell division, the tubes branch, too, under retention of the optical orientation of the calcite. Continued growth, cell division, and calcification result in laminae of Oocardium calcite (OC) concordant with substrate shape. $O$. stratum accelerates but seems not to control calcite precipitation. A maximum vertical calcification rate of $5 \mathrm{~mm} / \mathrm{a}$ was documented for a site $\sim 25 \mathrm{~m}$ downstream of the spring. 'Crystal-skeletal' OC characterized low calcite supersaturation, whereas higher supersaturation corresponded with rhombohedral OC. Abiotic precipitation downward of the upper tips of growing calcite tubes resulted in compact spar crystals, irrespective of initial crystal habit. Diatoms that thrived on OC benefit from a large differentiated habitat. Our study confirms previous works that identify $O$. stratum, not cyanobacteria, as major biocalcifiers in some hardwater springs. Diagenetically mature Oocardium tufa, however, may be confused with spring limestones of other origins.
\end{abstract}

Keywords Biocalcification $\cdot$ Microbial $\cdot$ Spring limestone $\cdot$ Oocardium $\cdot$ Calcareous tufa

\section{Introduction}

Precipitation of calcium carbonate causally associated with life, i.e., biocalcification, is a fundamental process in the secular development of Earth (e.g., Konhauser 2007). The role of cyanobacteria as major prokaryotic calcifiers has

Diethard Sanders

diethard.g.sanders@uibk.ac.at

1 Faculty of Geo- and Atmospheric Science, Institute of Geology, University of Innsbruck, Innrain 52, 6020 Innsbruck, Austria

2 Faculty of Biology, Institute of Botany, University of Innsbruck, Sternwartestraße 15, 6020 Innsbruck, Austria

3 Present Address: Department of Sedimentology and Marine Geology, Faculty of Geology, University of Science, Vietnam National University Ho Chi Minh City, 227 Nguyen Van Cu, Ho Chi Minh 700000, Vietnam been identified since the late 19th century, and continues to be investigated in many studies with different research focus (e.g., Gerdes and Krumbein 1987; Merz 1992; Riding 1992; Arp et al. 2001; Pratt 2001; Kawaguchi and Decho 2002; Pentecost 2005; Jones and Renaut 2010; Riding 2011; Jones 2017). Similarly, calcification associated with uni- and multicellular eukaryotes is comparatively well documented (e.g., McConnaughey and Whelan 1997; Gattuso et al. 1998; Stanley et al. 2002; Erba 2006; Pomar and Hallock 2008; Ries 2009; Jackson et al. 2011; Granier 2012; Gutner-Hoch et al. 2017; Wood et al. 2017). With respect to tufa formation in ambient-temperature spring streams, it was often implicitly underpinned that it is largely or entirely mediated by cyanobacteria and/or by mosses and, locally, by macroalgae such as Vaucheria. Conversely, the potential of eukaryotic microalgae to contribute to or even to dominate the limestone-precipitating biotic assemblage of springs was much more rarely identified. 
Only over the past decade or so, an increasing number of springs became identified in which calcification is largely mediated by the unicellular eukaryotic alga Oocardium stratum (Sanders and Rott 2009; Rott et al. 2010, 2012; Sanders et al. 2011; Ibarra et al. 2014; Linhart and Schagerl 2015; Cantonati et al. 2016; Trobej et al. 2017; Grüninger and Günzl 2018). This taxon belongs to the coccoid zygnemataleans (or desmids), a group of freshwater algae that is placed into the green algae sensu lato together with other ancestral lineages of land plants, such as the Charophyta (Streptophyta, e.g., Gontcharov et al. 2003). Zygnematalean algae date back at least to late Cambrian to Ordovician times (Gontcharov et al. 2003), and photosynthetic eukaryotes in freshwater habitats probably exist since the Proterozoic (e.g., Strother et al. 2011; Blank 2013; Wellman and Strother 2015).

Oocardium is a highly effective biocalcifier that typically forms crystals of calcite spar up to a few millimeters in size (e.g., Sanders and Rott 2009; Rott et al. 2012). Because $O$. stratum still is little known in the geoscientific community, to enable communication, the major characteristics of growth and calcification of this microalga are summarized first (Figs. 1, 2; Table 1). In all Oocardium calcites observed so far, irrespective of initial calcification style along the growing tips of the calcite tubes (cf. Fig. 1g, h), continued abiotic crystallization results in large crystals of calcite spar as final product (Fig. 1e, f) (Sanders and Rott 2009; Rott et al. 2012). The potential of $O$. stratum to build extensive limestone lithosomes has been known since the early 20th century (Wallner 1933, 1934a, b, 1935), but fell largely forgotten afterwards. In consequence, the physico-chemical limits, the life habits, and the synecological relations of $O$. stratum are still poorly known (Rott et al. 2012; Linhart and Schagerl 2015; Cantonati et al. 2016; Trobej et al. 2017). To date, aside a growing number of localities in Europe, the microalga was reported from North America, China, India, and Cuba (Rott et al. 2012; Linhart and Schagerl 2015; Trobej et al. 2017).

In the field, due to the small size of unicells, the presence of $O$. stratum is not easily detected. The few more detailed studies on the calcification of $O$. stratum indicate that it may be admixed to spring biota characterized by mosses and cyanobacteria, or that it strongly prevails and builds up lithosomes of a specific type of limestone (Sanders and Rott 2009; Rott et al. 2012; Linhart and Schagerl 2015). Other aspects of the ecology of $O$. stratum and its calcification remain unclear. Open questions are, for instance, Does it hibernate? How and when does it colonize substrates? Is there a seasonal change in calcification or synecology (e.g., with diatoms)? Does calcification correlate with calcite saturation state and $\mathrm{CO}_{2}$ concentration of the water? Here we describe the colonization and calcification of $O$. stratum over 13 months in a spring stream of the Eastern Alps.

\section{Setting}

The studied spring emerges from a wide terrace along the left side of the Inn valley, one of the major trunk valleys of the Eastern Alps (Fig. 3). The terrace is veneered by glacial till and by lacustrine and glacio-fluvial deposits (Starnberger et al. 2013). The studied spring is one of several springs and seepages that all emerge at $\sim 580 \mathrm{~m}$ a.s.l. from within the glacio-fluvial deposits (Ausserlechner 2012). The springline is located on a forested $\mathrm{N}$-facing slope that is shady the year over (Fig. 3c). The spring was chosen for study because (1) it is perennial, (2) it shows active calcification over the comparatively longest extent ( $45 \mathrm{~m})$ downstream, (3) its calcifying biota consists nearly exclusively of $O$. stratum, and (4) the water is a relatively 'simple', moderately mineralized $\mathrm{Ca}-\mathrm{Mg}-\mathrm{HCO}_{3}$ water (Table 2; Figs. 3c, 4a-c). The spring emerges on a gently sloping morphological step (Fig. 3c, 'spring area' in Fig. 4a) by confluence of seepages into a single streamlet.

Even after heavy snowfalls, the spring stream remained open to the sky (Fig. 5a). Because calcification exceeds stream incision, the stream flows over a moderately steep, ramp-like ledge composed of Oocardium tufa (Fig. 5b). Viable Oocardium cells, as indicated in the field by a light-green hue, were present over the entire observation period (3.2.2015-21.3.2016) (Fig. 5c). In the upper stream sector, from the spring to site 2 (cf. Fig. 4a), dark green to blackish tufts of filamentous cyanobacteria (e.g., Tolypothrix) are locally interspersed into Oocardium calcite but disappear downstream. Downstream of site 1, patches of filamentous zygnemataleans (Zygnema, Mougeotia, Spirogyra) are locally present, but are not identified as effective calcifiers. Besides $O$. stratum, only diatoms were recognized as important for total calcification mainly by processing new substrates for Oocardium settlement (see below). Along both margins of the waterrun ledge, a fringe of grass tufts and of the moss Palustriella commutatum is locally present (Fig. 5d). Downstream of site 3 (cf. Fig. 4a), part of the stream water re-infiltrates into the lithosome of spring limestone. Near site 4 (cf. Fig. 4a), the moss Eucladium verticillatum grows and calcifies within the stream. Moss calcification is due to overgrowth with $O$. stratum and is not considered separately hereunder.

Seasonal changes of biocolonization were subtle. Patches of viable Oocardium (Fig. 5c) were present all year over, but spread during late spring and autumn. Diatoms (mainly Achnanthes and Gomphonema) were common over the entire year. Although the diatoms were not investigated in detail, no obvious seasonal change of taxonomic composition was identified. Tufts of filamentous zygnemataleans spread in abundance during late spring. In autumn, downstream of site 3-site 4 (cf. Fig. 4a), wilted 

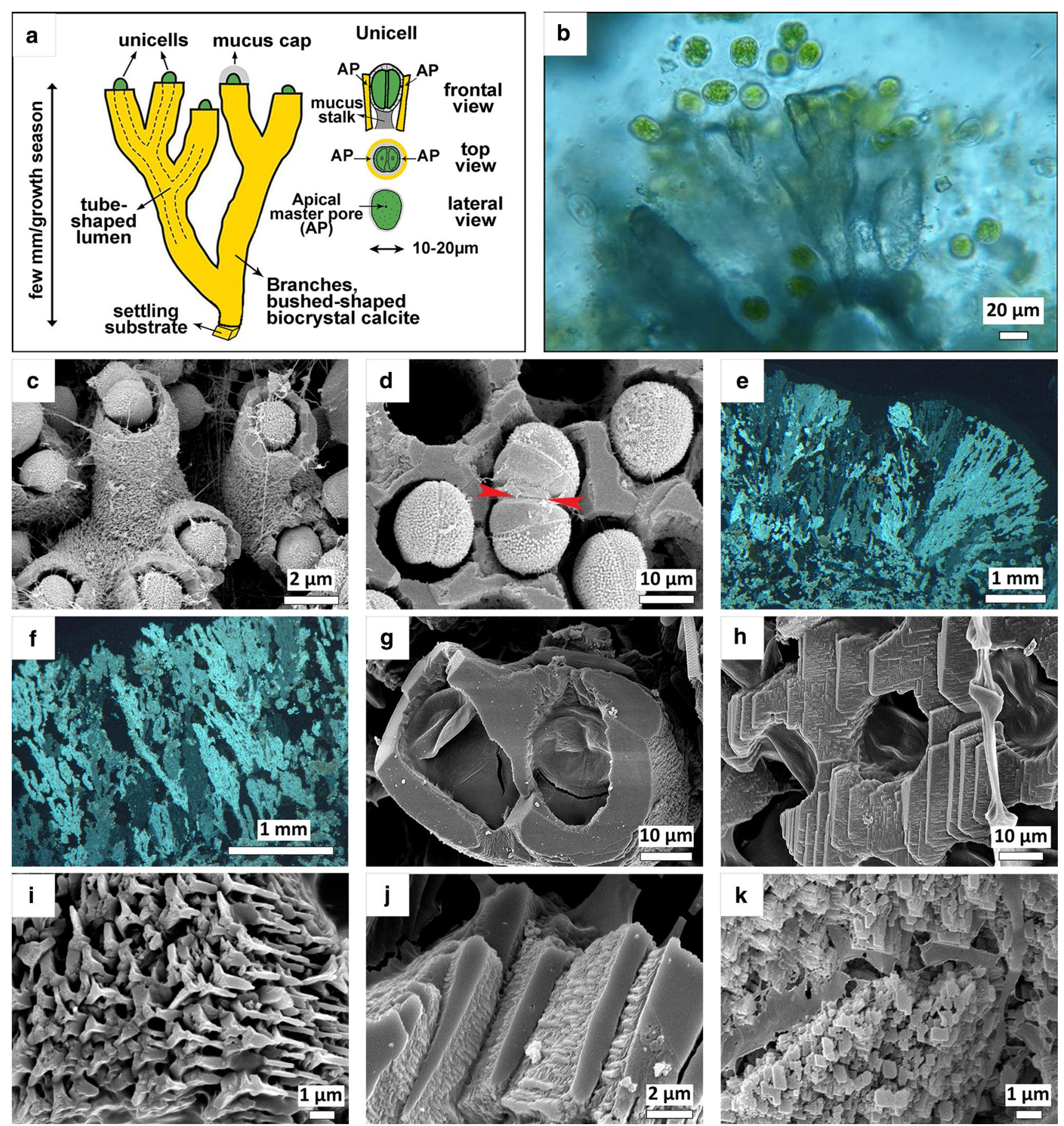

Fig. 1 Explanation of Oocardium stratum. a Scheme showing (1) branched, initially hollow calcite tubes (s) precipitated by the microalga, (2) position of cells (green) on a mucus stalk in the calcite tubes. Cells are fixed by holdfasts secreted from apical master pores (AP). b Transmitted light image of Oocardium calcite (OC) and green Oocardium cells. c, d $O$. stratum cells in their calcite tubes.

leaves of maples and alders locally covered up to an estimated $50-70 \%$ per square meter of the limestone surface (Fig. 5e). The waterrun upper sides of leaves provided substrates for biocolonization-calcification successions
Red arrows in $\mathbf{d}$ point to a dividing cell. e, $\mathbf{f}$ Thin sections of Oocardium calcite. Note large single calcite crystals. Crossed nicols. $\mathbf{g}-\mathbf{k}$ Terminology for shapes of calcite crystals that comprise the calcite tubes. $\mathbf{g}$ Massive; $\mathbf{h}$ stepped; $\mathbf{i}$ crystal-skeletal; $\mathbf{j}$ bladed; $\mathbf{k}$ microcrystallites. See text for further description

similar to those observed on experimental substrates (Fig. 5f). The autumnal input of leaves and its potential role for the biotic assemblage is discussed in more detail below. 

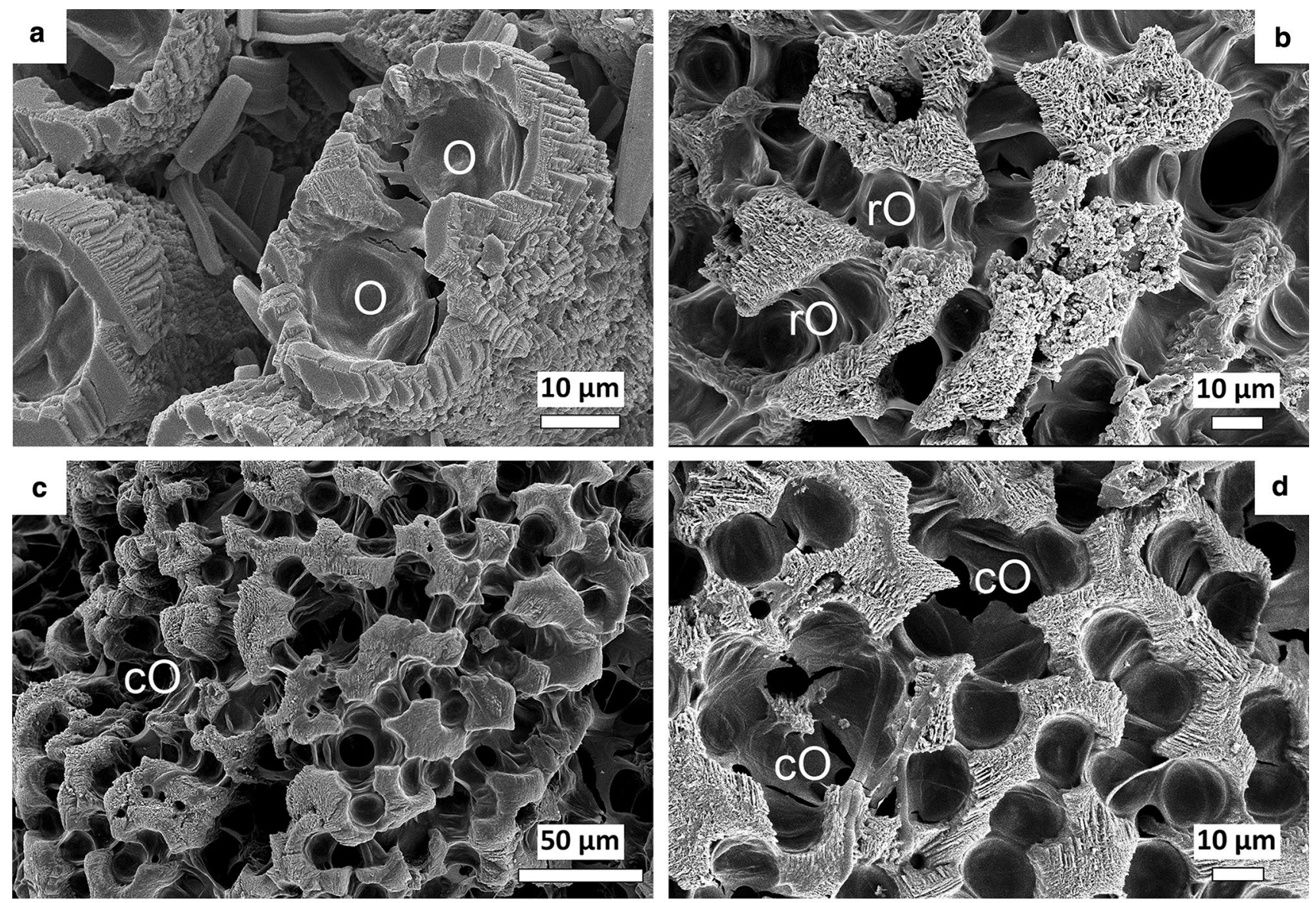

Fig. 2 Arrangement of $O$. stratum cells. a Two separate cells $(O)$ shortly after division. b Rows of Oocardium cells (rO) separated by 'walls' of calcite. c, d Clusters (cO) and rows of Oocardium cells

\section{Methods, definitions}

Documentation of Oocardium calcification described herein was started on February 3, 2015 and was repeated every 3 weeks until March 21, 2016. Microbotanical inspection under both reflected and transmitted light of fresh samples extracted in the field provided documentation of cyanobacteria and green algae. Microbotanical samples and samples for analysis of water chemistry were stored in a coolbox immediately after extraction from the field. Thin-sections of 21 dried and resin-impregnated samples of (1) natural Oocardium limestone and (2) of Oocardium calcite grown on experimental substrates provided data on calcite petrography, rates of vertical growth, and general aspects of fabric development. The spring stream was subdivided by four sites 1-4 (Fig. 4) each providing a fixed station for field measurement of physicochemical conditions of water, water sampling, placement of experimental substrates, and for judgment of the overall state of stream biota with changing season.
In the field, water temperature, electrical conductivity, and $\mathrm{pH}$ were measured with a calibrated multiparameter Combo Tester of Hannah Instruments ${ }^{\circledR}$. On every field visit, downstream, several water samples for full chemical analyses were taken. Water samples were carefully filled into 250-ml bottles. A few hours after field sampling and storage in a coolbox, the water samples were handed over to the Chemisch-Technische Umweltschutzanstalt of the Federal Government (Innsbruck city) for certified laboratory analyses. The PHREEQC Interactive program (version 3.3.7.11094) was used to calculate the equilibria of water samples (Parkhurst and Appelo 1999; Charlton and Parkhurst 2002, 2011). Calcite saturation index (SIcalcite) was applied as a measure of equilibrium according to the formula: SI $=\log (\mathrm{IAP} / \mathrm{KT})$, where: IAP-Ion Activity Product for ions forming minerals soluble in the given water solution, calculated according to the law of mass action for the $K$-equilibrium constant for a given reaction (Gradziński 2010). Free $\mathrm{CO}_{2}$ causing $\mathrm{pH}$ lowering at site 1 was analyzed using GRAN titration of samples kept isothermal in a coolbox as soon as possible after sampling. $\mathrm{CO}_{2}$ gas was 
Table 1 Descriptive terminology for growth and calcification fabrics of Oocardium stratum

\begin{tabular}{|c|c|}
\hline Criterion & Description, figure reference \\
\hline External shape of Oocardium calcite & $\begin{array}{l}\text { Lamina (laminar): laterally adjacent, vertically elongate 'bushes' (each from a parent cell) of } \\
\text { Oocardium calcite, similar in appearance to a thicket (Fig. 1a, f) } \\
\text { Pustule (pustular): hemispherical aggregate of tubes of Oocardium calcite, originated by } \\
\text { upward growth and multiple divisions of a parent cell (Fig. 7b) }\end{array}$ \\
\hline Cell arrangement & $\begin{array}{l}\text { Single celled: each tube of Oocardium calcite houses a single cell (Fig. 1a, c) } \\
\text { Double celled: a tube of Oocardium calcite houses two fully separate cells (cells after com- } \\
\text { plete division) (Fig. 2a) } \\
\text { Cell rows: straight to meandering rows of laterally adjacent Oocardium cells (Fig. 2b) } \\
\text { Cell clusters: clusters of Oocardium cells; within the clusters, cells are not separated by calcite } \\
\text { (Fig. 2c, d) }\end{array}$ \\
\hline $\begin{array}{l}\text { Calcite crystals per tube of Oocardium calcite } \\
\text { (applies only to single- and double-cell } \\
\text { arrangements) }\end{array}$ & $\begin{array}{l}\text { Single crystal: calcite tube consists of a single crystal or is part of a larger crystal (Figs. 1e, f, } \\
\text { 10b) } \\
\text { Multicrystal: calcite tube consists of two or more crystals, including crystal twins (Figs. 8e, } \\
11 \mathrm{e}, \mathrm{f} \text { ) }\end{array}$ \\
\hline $\begin{array}{l}\text { Crystallization style (as seen on top and upper } \\
\text { flanks of calcite tubes) }\end{array}$ & $\begin{array}{l}\text { Massive-idiomorphic: smooth surfaces of calcite rhombohedron well identifiable (Fig. 1g) } \\
\text { Stepped: growing surface of calcite crystal is compartmentalized into many steps, each delim- } \\
\text { ited by crystal surfaces of identical orientation (Fig. 1h) } \\
\text { Bladed: growing surface of calcite crystal is compartmentalized into 'blades' separated by } \\
\text { high steps or by empty space between; top of blades delimited by crystallographic surface } \\
\text { (Fig. 1j) } \\
\text { Crystal-skeletal: growing calcite crystal consists of numerous small crystal skeletons of identi- } \\
\text { cal orientation (Fig. 1i) } \\
\text { Microcrystalline (rare): growing calcite crystal consists of numerous sub-crystallites display- } \\
\text { ing rhombohedral shape (Fig. } 1 \mathrm{k} \text { ) }\end{array}$ \\
\hline $\begin{array}{l}\text { Terminology for crystal size according to Folk } \\
\text { (1974) }\end{array}$ & $\begin{array}{l}\text { Mini-micrite: crystals }<1 \mu \mathrm{m} \text { in size } \\
\text { Micrite: crystals } 1-4 \mu \mathrm{m} \text { in size } \\
\text { Microspar: crystals } 4-10 \mu \mathrm{m} \text { in size } \\
\text { Spar: crystals }>10 \mu \mathrm{m} \text { in size } \\
\text { Orthospar: crystals }>10 \mu \mathrm{m} \text { in size that grew into open pore space } \\
\text { Pseudospar: crystals }>10 \mu \mathrm{m} \text { in width that grew to final size by aqueous recrystallization }\end{array}$ \\
\hline
\end{tabular}

analyzed by gradual gas removal during back-titration to $\mathrm{pH}$ 8.3 (for further details see Rott et al. 2010). Duplicate titrations were performed to limit scatter.

To track colonization and calcification by Oocardium, we placed experimental substrates at sites 1-4 (Table 3). Based on earlier experiences, we used diverse natural and artificial substrates not only to provide colonization surface but also to test the effects of complex substrate space and outer day-lit versus inner dark or low-lit surfaces. Substrates were placed at different times over the observation period. Most substrates were sampled on each or every second field visit (interval of 3-6 weeks) by carefully chipping off a small piece for inspection by electron microscopy. In the laboratory, the SEM samples were air dried at room temperature. Calcification rate was determined by measurement from SEM images and from thin sections of Oocardium calcite grown on experimental substrates. Documentation was centered on backscattered electron microscopy of Oocardium colonization and calcification on diverse experimental substrates relative to the physico-chemistry of stream water at site. Imaging and analyses of samples by scanning electron microscopy (SEM) were carried out with a JEOL Model JSM-6010 LV. The samples were mounted on carbon tape and gold sputtered. SEM analysis provided a magnification range from $20 \times$ to $30,000 \times$, with a maximum resolution of $0.5 \mu \mathrm{m}$ (secondary electron image), an acceleration voltage of $10 \mathrm{kV}$, and an optional high-vacuum and low-vacuum operation mode. Backscattered electron shadow images were acquired at low vacuum with an acceleration voltage of $15 \mathrm{kV}$ (Perfler et al. 2015, 2016). Due to air drying, in SEM, Oocardium cells look similar to deflated soccer balls but remain well identifiable as such.

Herein, we use the term 'abiotic' for calcite crystals and fabrics thereof that apparently grew, or that continued to grow, without decisive interaction with organisms as far as identifiable in SEM at magnifications up to $15-20 \mathrm{k}$. This does not necessarily exclude that the crystals initially were related to bio- or organofilms. The terminology to designate crystal sizes is according to Folk (1974) (Table 1). In the following, the natural state of the spring limestone and the results from experimental substrates placed for precipitation of Oocardium 

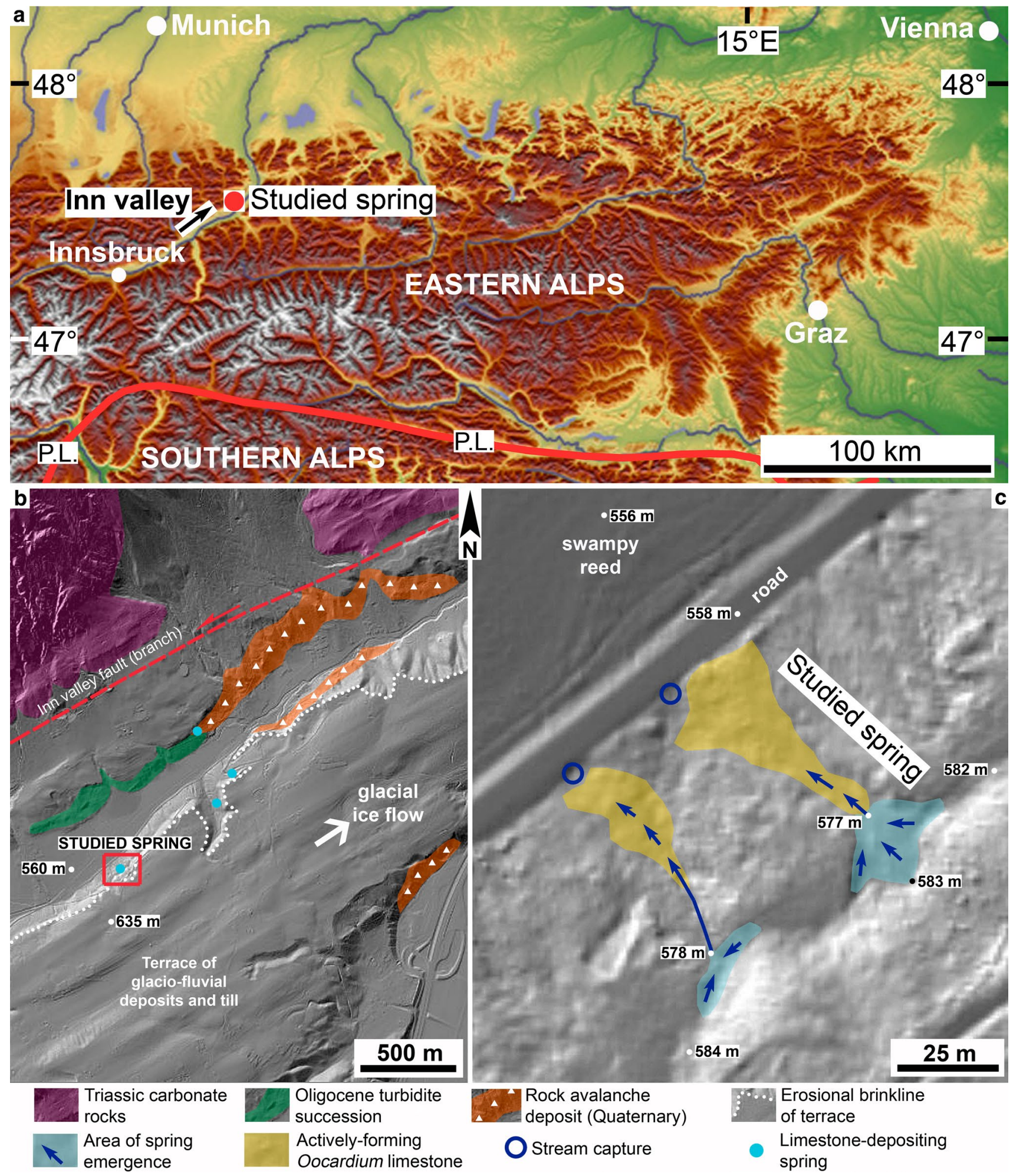

Fig. 3 a Position of studied spring in the Eastern Alps. b, c Local geological setting of spring. Calcification was studied at four downstream sites $1-4$. Site 1: $47.520407^{\circ} \mathrm{N} / 12.043665^{\circ} \mathrm{E}$; site 2:

$47.520439^{\circ} \mathrm{N} / 12.043610^{\circ} \mathrm{E}$; site $3: 47.520472^{\circ} \mathrm{N} / 12.043536^{\circ} \mathrm{E}$; site 4 : $47.520556^{\circ} \mathrm{N} / 12.043222^{\circ} \mathrm{E}$. Site coordinates in decimal notation. See text for further description 
Table 2 Average values and minimum-maximum range of physicochemical parameters of the water of the studied spring

\begin{tabular}{lll}
\hline & Average $(n=58)$ & Minimum/maximum \\
\hline Temperature $\left({ }^{\circ} \mathrm{C}\right)$ & 9.03 & $4.87 / 15.63$ \\
$\mathrm{pH}$ & 8.03 & $7.12 / 8.7$ \\
Electrical conductivity $(\mu \mathrm{S} /$ & 555.96 & $428.67 / 679.33$ \\
$\quad \mathrm{~cm})$ & & \\
$\mathrm{Ca}^{2+}(\mathrm{mg} / \mathrm{l})$ & 84.54 & $61.8 / 99.3$ \\
$\mathrm{Mg}^{2+}(\mathrm{mg} / \mathrm{l})$ & 27.61 & $21.4 / 31.6$ \\
$\mathrm{Mg}^{-\mathrm{Ca} \mathrm{molar} \mathrm{ratio}}$ & 0.55 & $0.46 / 0.71$ \\
$\mathrm{Na}^{+}(\mathrm{mg} / \mathrm{l})$ & 2.76 & $2.21 / 3.4$ \\
$\mathrm{~K}^{+}(\mathrm{mg} / \mathrm{l})$ & 2.74 & $2.21 / 3.64$ \\
$\mathrm{HCO}_{3}{ }^{-}(\mathrm{mg} / \mathrm{l})$ & 396.12 & $335 / 441.75$ \\
$\mathrm{CO}_{2}(\mathrm{mg} / \mathrm{l})$ & 18.44 & $3.15 / 53.14$ \\
$\mathrm{SI} \mathrm{calcite}(\mathrm{PHREEQC})^{2}$ & 0.9 & $0.08 / 1.47$ \\
$\left(\mathrm{SO}_{4}\right)^{2-}(\mathrm{mg} / \mathrm{l})$ & 4.4 & $3.6 / 6.46$ \\
$\mathrm{Cl}^{-}(\mathrm{mg} / \mathrm{l})$ & 2.79 & $2.14 / 3.65$ \\
$\mathrm{NO}_{3}{ }^{-}(\mathrm{mg} / \mathrm{l})$ & 5.63 & $4.86 / 7.33$ \\
$\mathrm{Total}^{\mathrm{p}}$ phosphorus $(\mathrm{mg} / \mathrm{l})$ & $<15$ & $<15 / 21$ \\
\hline
\end{tabular}

See Fig. 4 for downstream changes of parameters

calcite are described downstream from sites 1-4 (cf. Fig. 4; Tables 3 and 4). The term 'green Oocardium calcite' denotes that most or all of the calcite tubes (cf. Figs. 1, 2) are inhabited by living $O$. stratum cells; conversely, 'white Oocardium calcite' indicates a limestone that consists of calcite tubes as diagnostic of $O$. stratum calcification, but with only a few or no living cells within their tubes. For samples of Oocardium calcite that were taken from the natural stream bed, we use the term 'natural Oocardium calcite', whereas calcite precipitated on experimental substrates is briefly named 'grown Oocardium calcite' or 'Oocardium calcite grown on'.

\section{Results}

\section{Downstream calcification}

\section{Site 1}

At this site, the natural stream bed was paved mainly with white Oocardium calcite, but interspersed with smaller patches of green Oocardium calcite (Table 4); the green patches persisted the entire year over. The white Oocardium calcite showed as empty tubes in crystal-skeletal to bladed crystallization style (Fig. 6a, b). The patches of green Oocardium calcite, however, typically consisted of 'walls' of calcite laterally separating rows of $O$. stratum cells (Fig. 2) or, locally, of 'pillars' of calcite within clusters of $O$. stratum cells; in both cases, the calcite also showed crystal-skeletal to bladed crystallization style (Fig. 6c, d). When- and wherever sampled, at site 1, green Oocardium calcite always showed crystal to, more rarely, bladed crystal fabric.

Despite the presence of green Oocardium cells at site 1 over the entire year, this site remained inert with respect to colonization and calcification of experimental substrates by $O$. stratum (cf. Table 3 ). Substrates were colonized by biofilms of diatoms and undetermined bacteria, and with scattered nanometer- to micrometer-scale crystals of calcium carbonate (Fig. 6e). Overall, the density of calcification with small-sized crystals increased within the bacterial-diatom biofilms over the observation period (Fig. 6f). Macroscopically, the rinse fleece remained soft and uncalcified as it was when placed into the stream. In summary, except for a low rate of calcification associated with diatoms and bacteria, site 1 remained practically inert over more than a year with respect to Oocardium colonization and calcification.

\section{Site 2}

At site 2, green Oocardium cover prevailed all over the year (Fig. 5c). The natural Oocardium calcite sampled from this site is characterized by cell rows and clusters, and by crystalskeletal to bladed initial calcification (Fig. 7a). Experimental substrates typically were colonized by Oocardium within 3 weeks after placement (see Table 3). On most substrates, Oocardium calcified in bladed to massive style, and with cells typically arranged in rows and clusters (Fig. 7b-d). At site 2, pustules of Oocardium calcite grew at a rate of 55 and $78 \mu \mathrm{m} / \mathrm{month}(n=2)$ (Table 4$)$.

\section{Site 3}

Here, the natural Oocardium calcite was characterized by massive-idiomorphic initial calcification (Fig. 7e). Whereas Oocardium was clearly prevalent, intercalated patches colonized by diatoms were present. The diatom patches were associated with cumulates of (sub)micron-sized calcite crystals that presumably had precipitated within the mucus of the diatom mats (Fig. 7f). At site 3, all precipitation substrates were colonized by diatoms and bacteria within 3 weeks, and first settlement and early calcification by Oocardium required 3-6 weeks, i.e., one to two check intervals in duration. Oocardium consistently calcified in massive-idiomorphic or, more rarely, bladed style all over the year (Table 3).

The different experimental substrates showed specific styles of initial Oocardium colonization. (a) Substrates completely overrun by water, such as rinse fleece, became more-or-less equally colonized. Three patches of rinse fleece placed during spring and winter (see Table 3 for dates) all were colonized by diatoms and Oocardium within 3 weeks after placement. The Oocardium cells settled on the fleece 


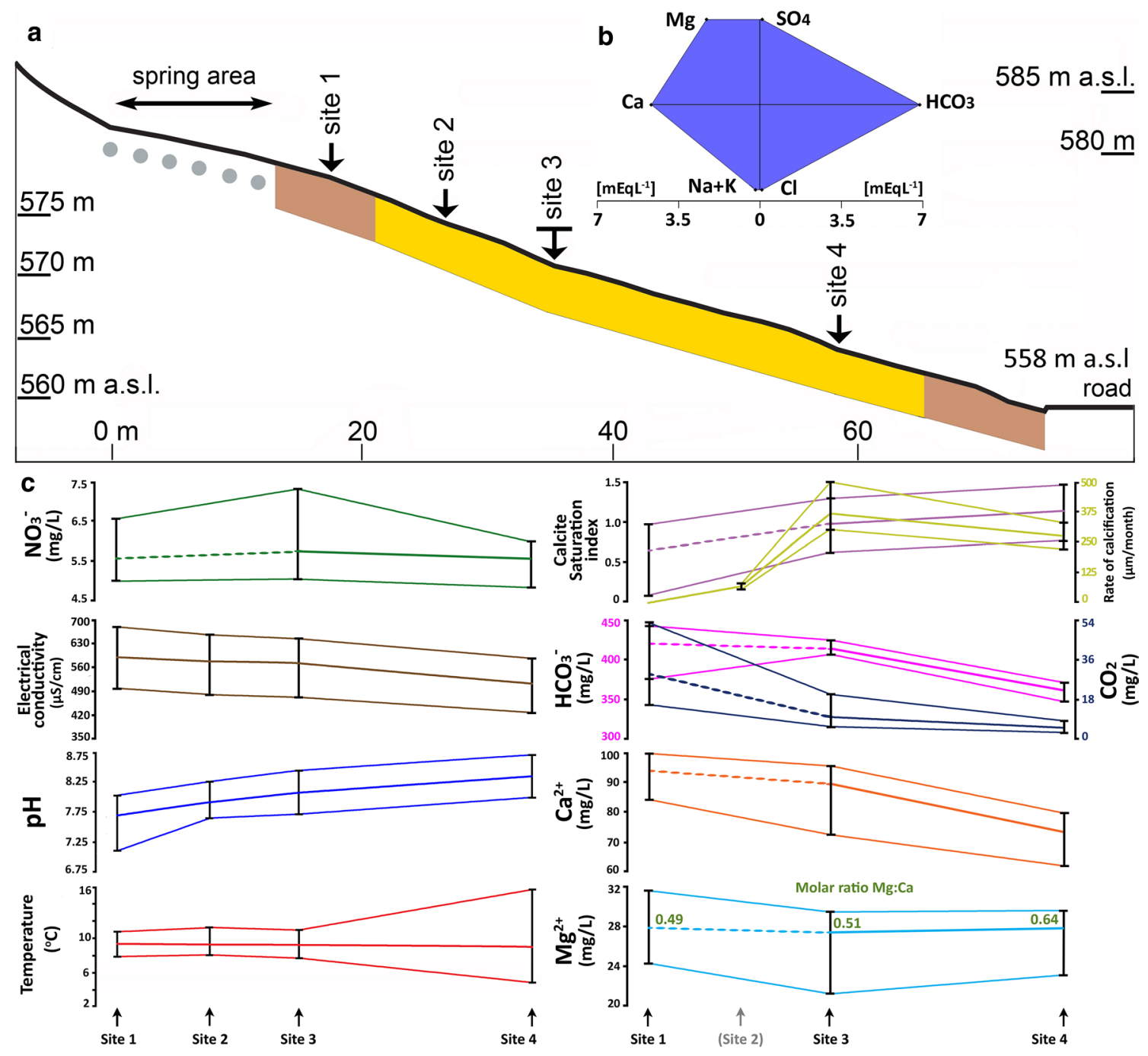

Fig. 4 a Section down spring stream. The physico-chemistry and the biota were mainly studied at sites $1-4$. At site 3 , numerous experimental substrates (see text) were distributed over a downstream dis-

tance of $\sim 2 \mathrm{~m}$. b Stiff plot to indicate mean cationic/anionic chemistry of the stream. c Downstream changes of major physico-chemical parameters

surface coalesced into a continuous layer of massive-idiomorphic calcite (Fig. 8a, b). (b) Substrates that projected out of stream flow, such as small flowerpots (Table 3), became first colonized and calcified by Oocardium along the downstream (lee) side, and near the interface between stream and atmosphere. Notably, the lower fringe of the low-lit inner side of flowerpots also became colonized by Oocardium cells; these cells had started to calcify but died soon after settlement and early calcification (Fig. 8c-e). (c) The sharpedged plastic strips first became colonized by diatoms and bacteria; within these biofilms, isolated crystals and crystal clusters of calcite precipitated. Oocardium colonization, in contrast, always started along the edges of the strips. Only later, when a crust of calcite crystals or wider crystal clusters had precipitated on the upper surface of the strips, had Oocardium also settled there (Figs. 8f; 9a, b). (d) Finally,

plastic cords that waved freely in shooting stream flow also became colonized by diatoms and Oocardium as readily as fixed substrates. Oocardium colonization on the cords took place also during winter, and green cells within calcite tubes of massive-idiomorphic crystallization style persisted over the winter (Fig. 9c-f).

At site 3, the documented rates of calcification were highest. SEM observations and thin-sections of experimental substrates indicate that the Oocardium calcite grew vertically at a rate of 300-370-500 $\mu \mathrm{m} / \mathrm{month}(n=9)$ (Table 4). In precipitation substrates with a large pore space-such as rinse fleece, loofah, or small boxes of balsa wood-(see Table 3), the low-lit (rinse fleece, loofah) or dark (wood box) pore space became filled mainly by micropeloidal grainstone to packstone whereas the daylit outer surfaces were colonized by calcifying Oocardium (Figs. 9a, 10b-d). 

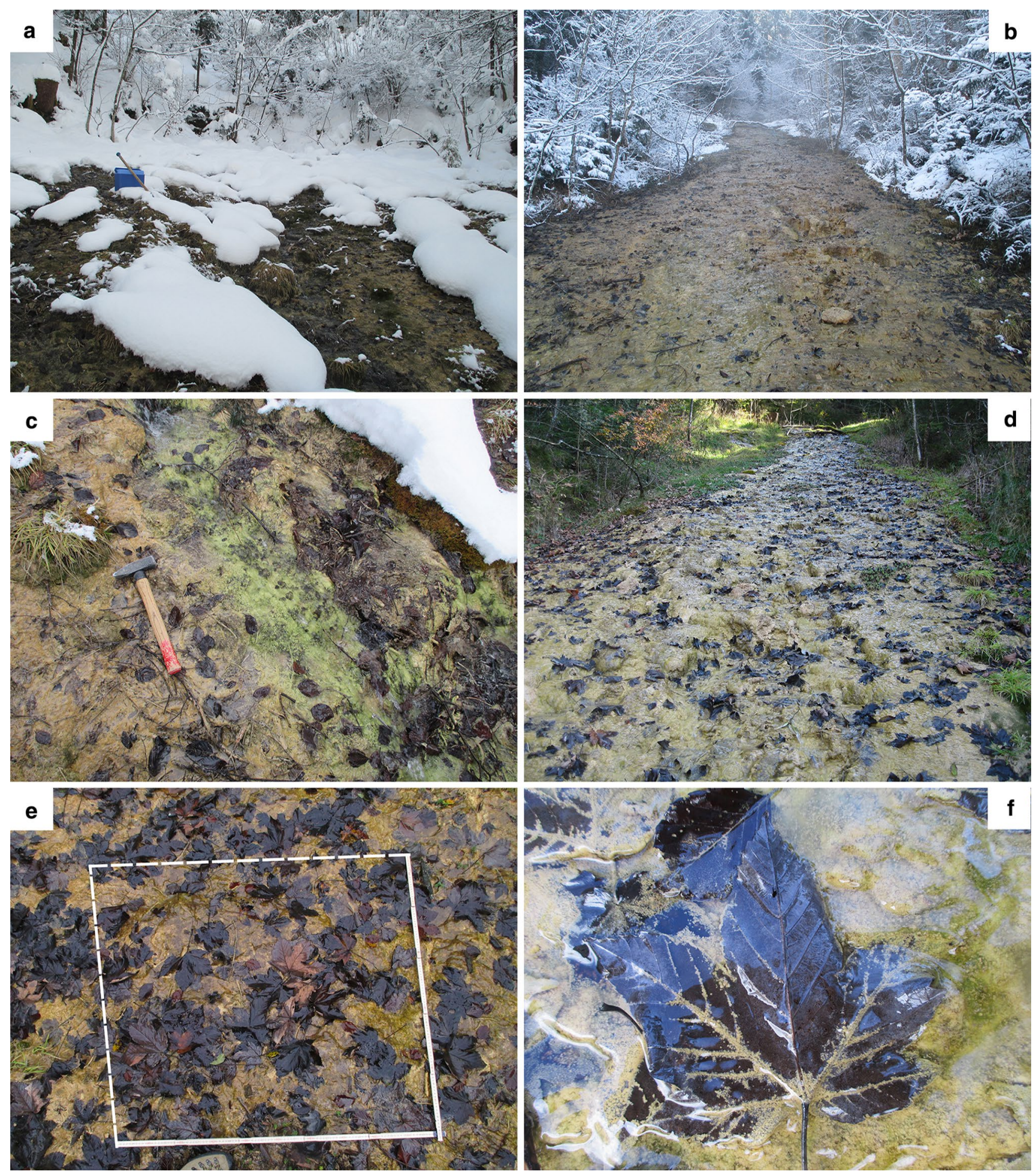

Fig. 5 a Spring area on 2.3.2015 after heavy snowfall. b View up the spring stream on 7.1.2016. c Active Oocardium calcite (green hue on stream bed), and Oocardium calcite with only a few viable cells (brownish hue); 3.2.2015. d View upstream, 6.11.2011. Note leaves

fallen into the stream, and marginal fringes of grass tufts and moss. e Stream bed on 12.10.2015 between site 3 and site 4 (cf. Fig. 3a), littered with wilted leaves. $\mathbf{f}$ Maple leaf on stream bed. Calcification starts along the protruding leave veins; 23.11.2015 


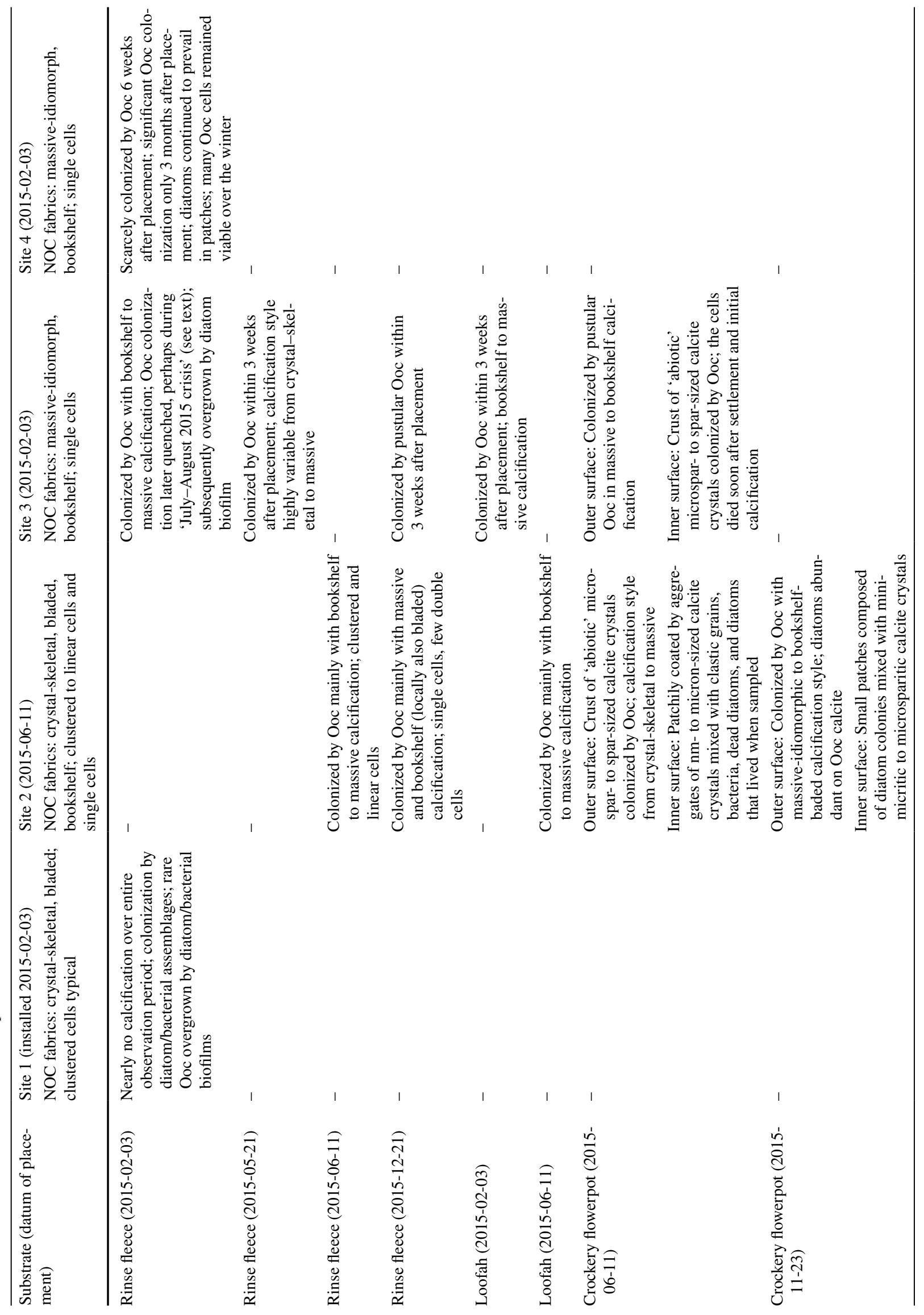


Facies (2019) 65:37

Page 11 of $24 \quad 37$

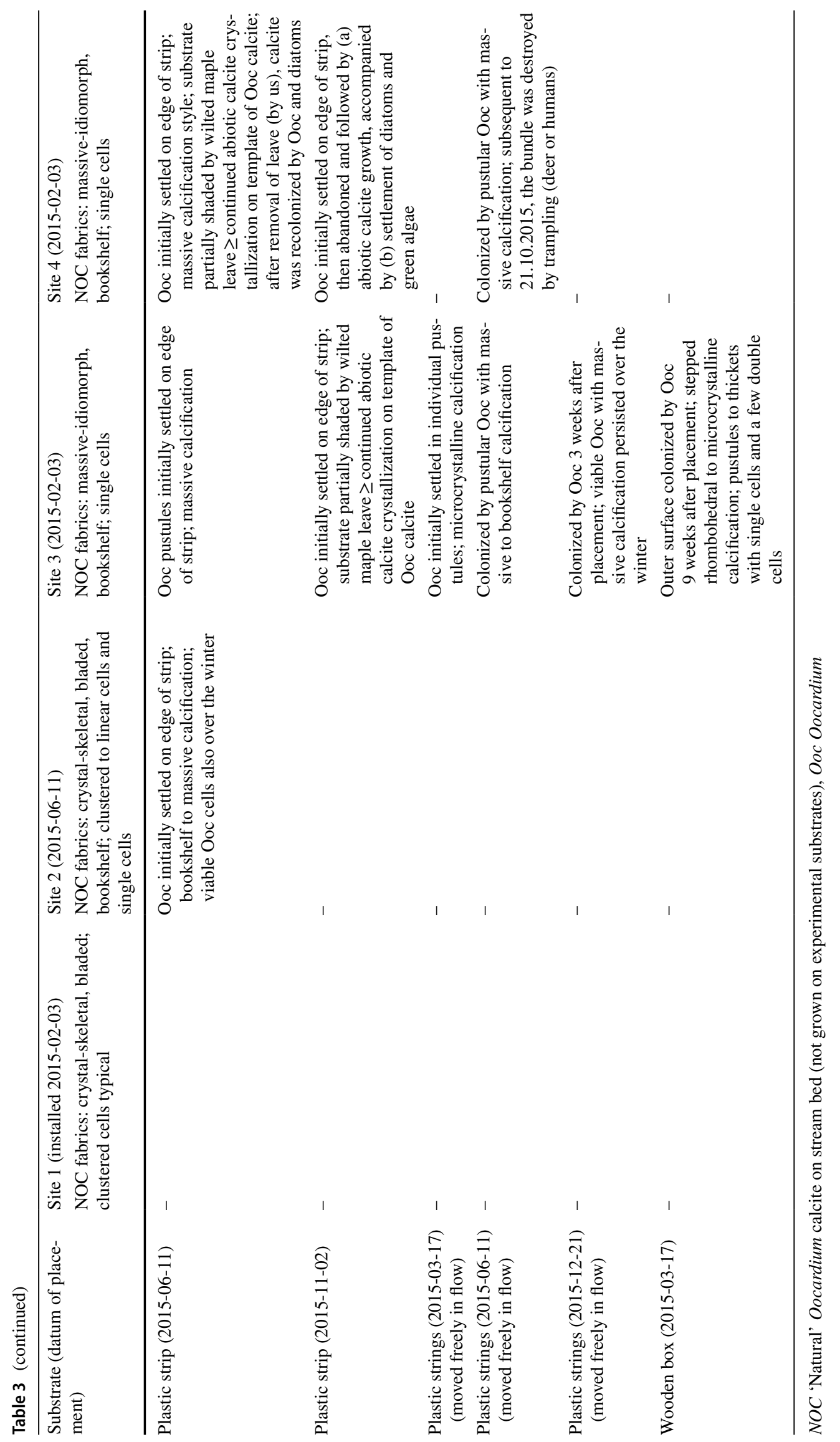

Springer 
Table 4 Characterization of downstream sites 1-4 (see Fig. 4)

\begin{tabular}{|c|c|c|c|c|c|}
\hline & Stream bed & $\begin{array}{l}\text { Oocardium cell arrange- } \\
\text { ment }\end{array}$ & $\begin{array}{l}\text { Initial crystallization style } \\
\text { of Oocardium calcite }\end{array}$ & $\begin{array}{l}\text { Rates of Oocardium } \\
\text { calcification }(\mu / \text { month })\end{array}$ & Remarks \\
\hline Site 1 & $\begin{array}{l}\text { Mainly WOC, patches of } \\
\text { GOC }\end{array}$ & Rows and clusters & Crystal-skeletal to bladed & Zero & $\begin{array}{l}\text { Experimental substrates } \\
\text { remained uncalcified } \\
\text { by } O . \text { stratum }\end{array}$ \\
\hline Site 2 & $\begin{array}{l}\text { Mainly GOC, patches of } \\
\text { WOC }\end{array}$ & Rows and clusters & Crystal-skeletal to bladed & $\begin{array}{l}55 \mu / \text { month; } 78 \mu \text { /month } \\
\quad(n=2)\end{array}$ & - \\
\hline Site 3 & $\begin{array}{l}\text { Mainly GOC, patches of } \\
\text { WOC }\end{array}$ & Single cells & $\begin{array}{l}\text { Massive-idiomorphic, } \\
\text { rarely bladed }\end{array}$ & $\begin{array}{l}300-370-500 \mu / \text { month } \\
\quad(n=9)\end{array}$ & - \\
\hline Site 4 & $\begin{array}{l}\text { GOC and WOC, season- } \\
\text { ally strongly changing }\end{array}$ & Single cells & Massive-idiomorphic & $\begin{array}{l}220 \mu / \text { month; } 330 \mu / \\
\text { month }(n=2)\end{array}$ & $\begin{array}{l}\text { Stream bed was peren- } \\
\text { nially overrun by a } \\
\text { 'sheet' } \sim 1-3 \mathrm{~mm} \text { thick } \\
\text { of water }\end{array}$ \\
\hline
\end{tabular}

For terms related to cell arrangement and initial crystallization style of $O$. stratum, see Table 1 and Fig. 1

WOC White Oocardium calcite, GOC Green Oocardium calcite. See text for further description

\section{Site 4}

Downstream of site 3 , the spring stream divides and widens, and the water re-infiltrates into the body of spring limestone. As a consequence, stream flow is a sheet of water $\sim 1-3 \mathrm{~mm}$ in thickness at site 4 , yet perennial. Hence, the choice of precipitation substrates was more limited. The natural Oocardium calcite at site 4 showed massive-idiomorphic initial crystallization. A piece of rinse fleece placed on February 3, 2015, and overrun by a thin film of water, required 6 weeks for diatom colonization; in addition, rare Oocardium was found (Fig. 11a, b). Sizeable colonization by pustular clones of Oocardium with massive-idiomorphic crystallization occurred only 3 months after substrate placement; overall, diatoms remained the most abundant colonizers. Only slowly, and probably with increasing overall calcification, the density of Oocardium cover increased, but large patches colonized only by diatoms remained. Over the winter of 2015 to 2016, Oocardium remained in part viable, and the calcite tubes provided a substrate for cover by diverse diatoms (Fig. 11c). Conversely, the two precipitation substrates placed on June 11, 2015 (Table 3) were colonized by diatoms and calcifying $O$. stratum within the 3-week check interval after placement. At site 4, despite an overall high calcite saturation index, rates of calcification are lower (cf. Fig. 4). Oocardium calcified at an averaged rate of 220 and $330 \mu \mathrm{m} / \mathrm{month}(n=2)$ (Table 4$)$. Downstream of site 4, watershed progressively dwindles, and precipitation of spring limestone tapers out within a few meters (Fig. 4).

\section{Oocardium settlement and early calcification}

Calcite substrate was first colonized by single cells of $O$. stratum. Initially, a cell settled and held fast on what appears to be an organic 'glue' secreted by the cell. This phase of settlement was only rarely observed (Fig. 11d).
Subsequently, while still attached to the initial place of settling, the cells became fringed by calcite crystals (Fig. 11d, e). Next, when the calcite crystals had precipitated to size, in most cases, the cell seemed to grow up for a small vertical distance (i.e., a short mucus stalk had developed; Figs. 11f, 12a) and then underwent its first division. Upon progressive calcification and cell divisions, a multicellular pustule of Oocardium calcite developed by (a) vertical growth of calcite tubes, combined with (b) ongoing cell division and, hence, branching of calcite tubes. As mentioned, the optical orientation of the calcite is retained upon cell division and branching of calcite tubes, resulting in single large biocrystals (cf. Fig. 10a-d).

Downward along the tubes of Oocardium calcite, the mucus stalks disappeared, and the lumen of the tube was filled by calcite with identical optical orientation to its housing calcite tube. In SEM, broken calcite tubes also showed that despite the wide range in initial calcite crystallization, within at most a few tens of microns downward from the tube top, the inner part of the tube walls consisted of massive (non-porous) calcite. All types of precipitation substrates with distinct edges were first colonized by Oocardium along the edges (cf. Figs. 8f; 9a, b). Where wider areas were colonized by Oocardium, markedly different stages of growth-ranging from single cells in initial calcification to fully developed multicellular pustules as described-indicate that after the initial lag phase, colonization is continuously taking place.

\section{Relation of Oocardium to bacteria and diatoms}

At all sites, precipitation substrates were initially colonized by bacteria and diatoms; in no case, Oocardium was the first colonizer of substrates. Recall that the precipitation substrates included only 'non-calcitic materials' (wood, plastic, etc.) (Table 3). On calcitic surfaces, in turn, individual 

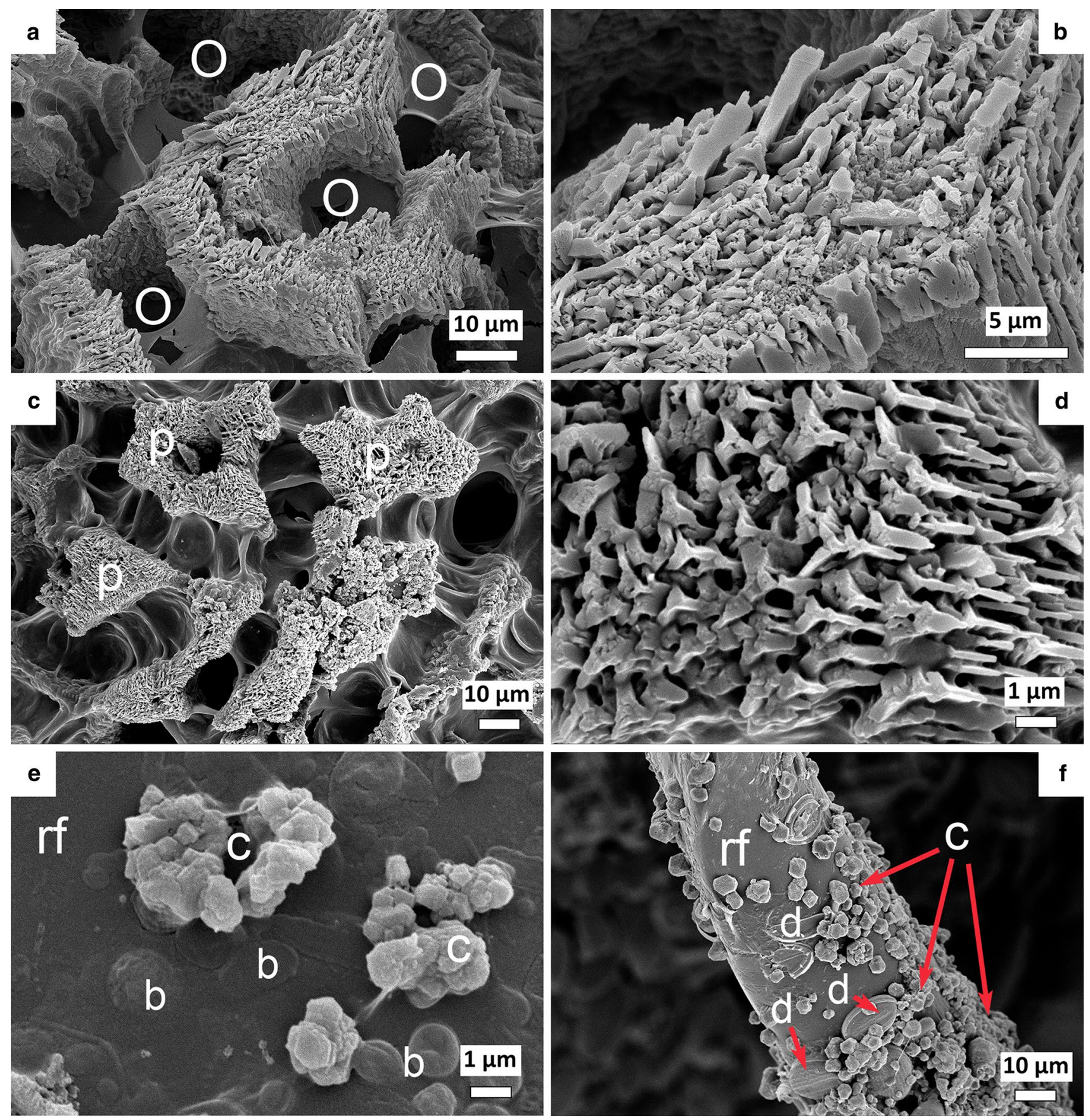

Fig. 6 a Site 1 (cf. Fig. 3): natural white Oocardium calcite in skeletal crystallization style (O: sites without $O$. stratum cells). b Detail of crystal-skeletal fabric of subfigure a. c Site 1: detail from a patch of natural green Oocardium calcite. Rows of Oocardium cells intercalated by calcite 'pillars' (p) with crystal-skeletal fabric. d Crystal-

Oocardium cells settled directly. On the precipitation substrates, the early bacterial-diatom biofilms were associated with mini-micritic to sparitic calcite crystals that were isolated and/or comprised clusters and patches (Fig. 12b; see also Fig. 6e, f). skeletal fabric of subfigure c. e Site 1: experimental substrate (rf, rinse fleece) colonized by unspecified bacteria (b). Note submicronto micron-sized calcite crystals (c). f Site 1: plastic fiber of rinse fleece (rf) colonized by diatoms (d), 13.5 months after placement. Note cover of calcite crystals (c)

In fully developed fabrics of Oocardium calcite inhabited by living cells, bacteria were rare to most commonly absent. Conversely, diatoms were widely associated with living $O$. stratum. The diatom flora observed on the Oocardium calcite was dominated by Achnanthes and Gomphonema; in 

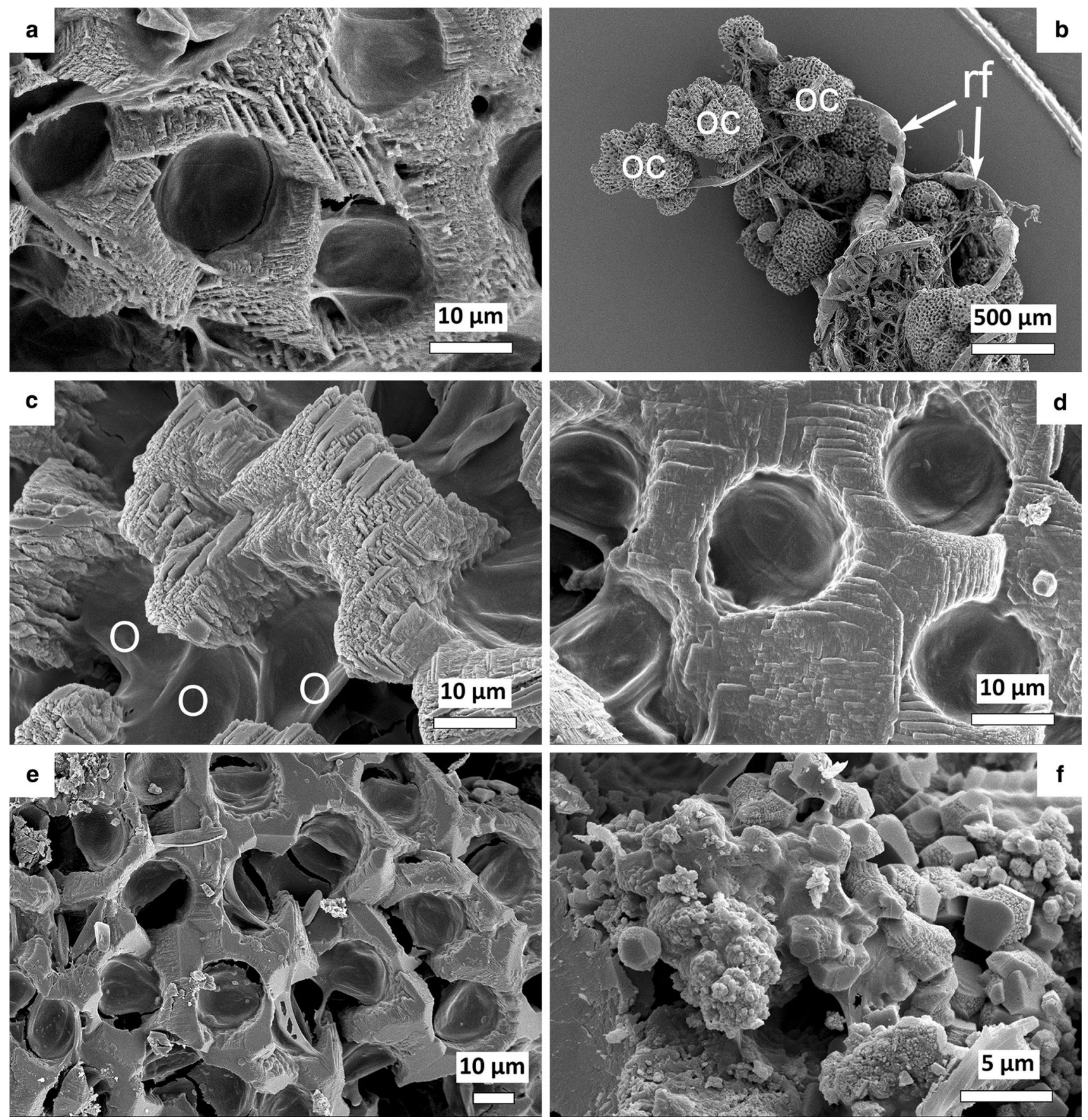

Fig. 7 Downstream changes of Oocardium calcification. a Site 2: natural green Oocardium calcite with crystal-skeletal calcification. b Site 2: rinse fleece (rf) overgrown by spherical Oocardium calcite (OC) each comprising numerous cells. Substrate placed 11.6.2015; sampled 2.11.2015. c Detail of subfigure b: bookshelf calcification,

addition, a number of other less widespread forms was present (e.g., Navicula, Synedra, Diatoma, Cymbella, Fragilaria, Cocconeis). Diatom colonization ranged from dense aggregations (Fig. 12c, d) to a few frustules scattered on and between Oocardium calcite tubes. The diatoms settled and short row of Oocardium cells $(O)$. d Site 2: green Oocardium calcite (grown on rinse fleece) showing stepped calcification. Substrate placed 11.6.2015; sampled 21.3.2016. e Site 3: natural Oocardium calcite in massive calcification style. f Site 3: detail of a patch of calcite crystallites typically associated with diatom mats on the large surface provided by the arrays of calcite tubes, and/or settled and grew up between the tubes (Fig. 12e). Even in case of very dense diatom colonization, however, provided that Oocardium calcite tubes were inhabited by cells when sampled, the top of the calcite tubes was free 

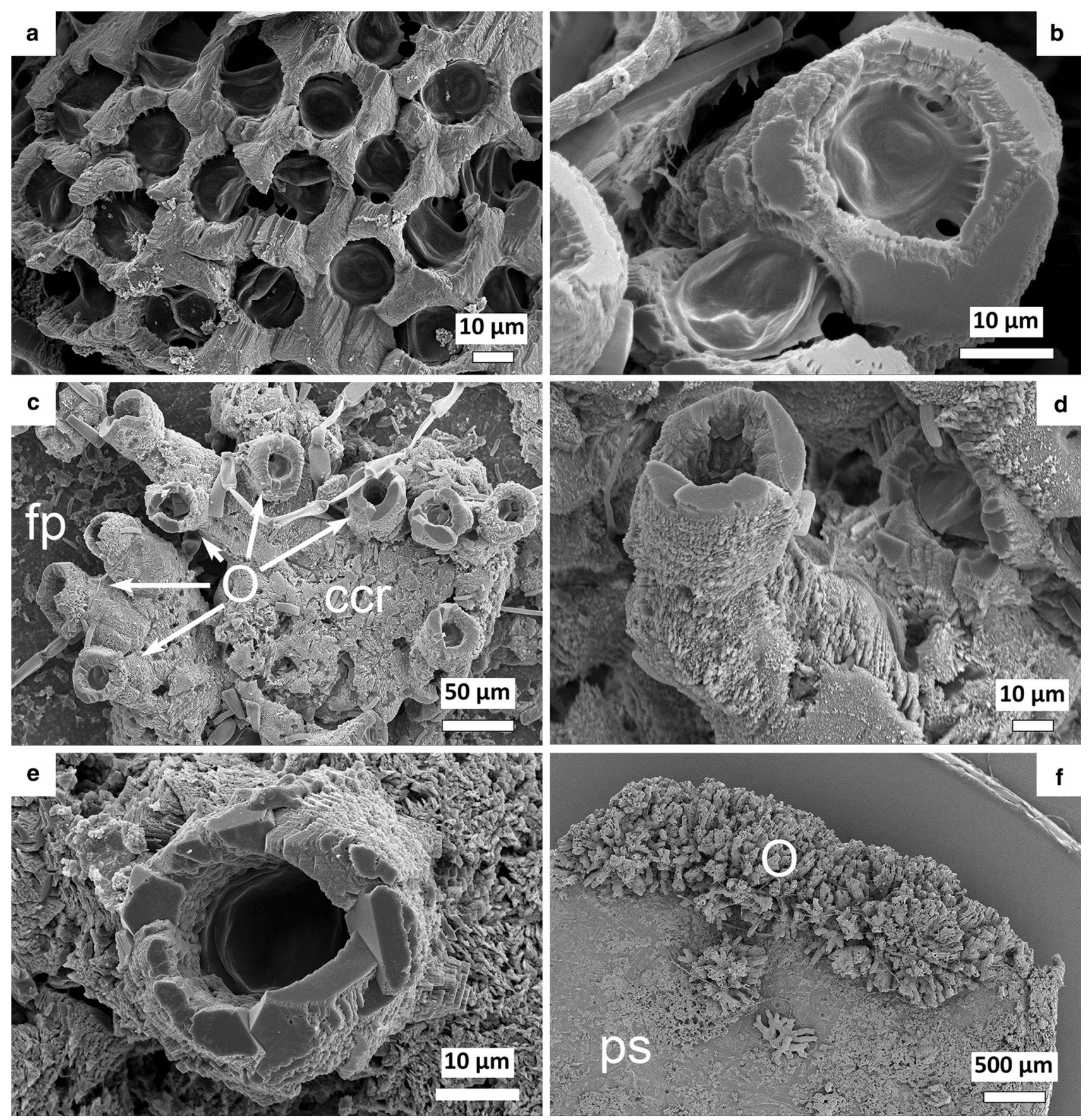

Fig. 8 Oocardium calcites grown on experimental substrates. a Site 3: Oocardium calcite on rinse fleece placed on 3.2.2015; sampled 30.6.2015. b Site 3: Oocardium calcite (massive calcification) on rinse fleece placed on 21.12.2015; sampled 21.3.2016. c Site 3: day-lit side of flowerpot (fp) colonized by Oocardium $(O)$ settled on a calcite crust (ccr). Substrate placed 11.6.2015; sampled 22.9.2015.

of diatoms; only on abandoned tubes, diatoms settled on the top (Fig. 12f). Where patches of abandoned Oocardium calcite became overgrown by diatom films, cumulates of d Oocardium calcite tube on the outer side of the flowerpot. e Site 3: abandoned Oocardium calcite on the inner, nearly dark side of a flowerpot fixed in the stream. Substrate placed 11.6.2015; sampled 22.9.2015. f Site 3: colonization of plastic strip (ps) by Oocardium $(O)$ along the edges of the strip. Substrate placed 11.6.2015; sampled 2.11.2015

micron- to submicron-sized calcite crystals closely similar to those observed in first colonization of experimental substrates were seen. 

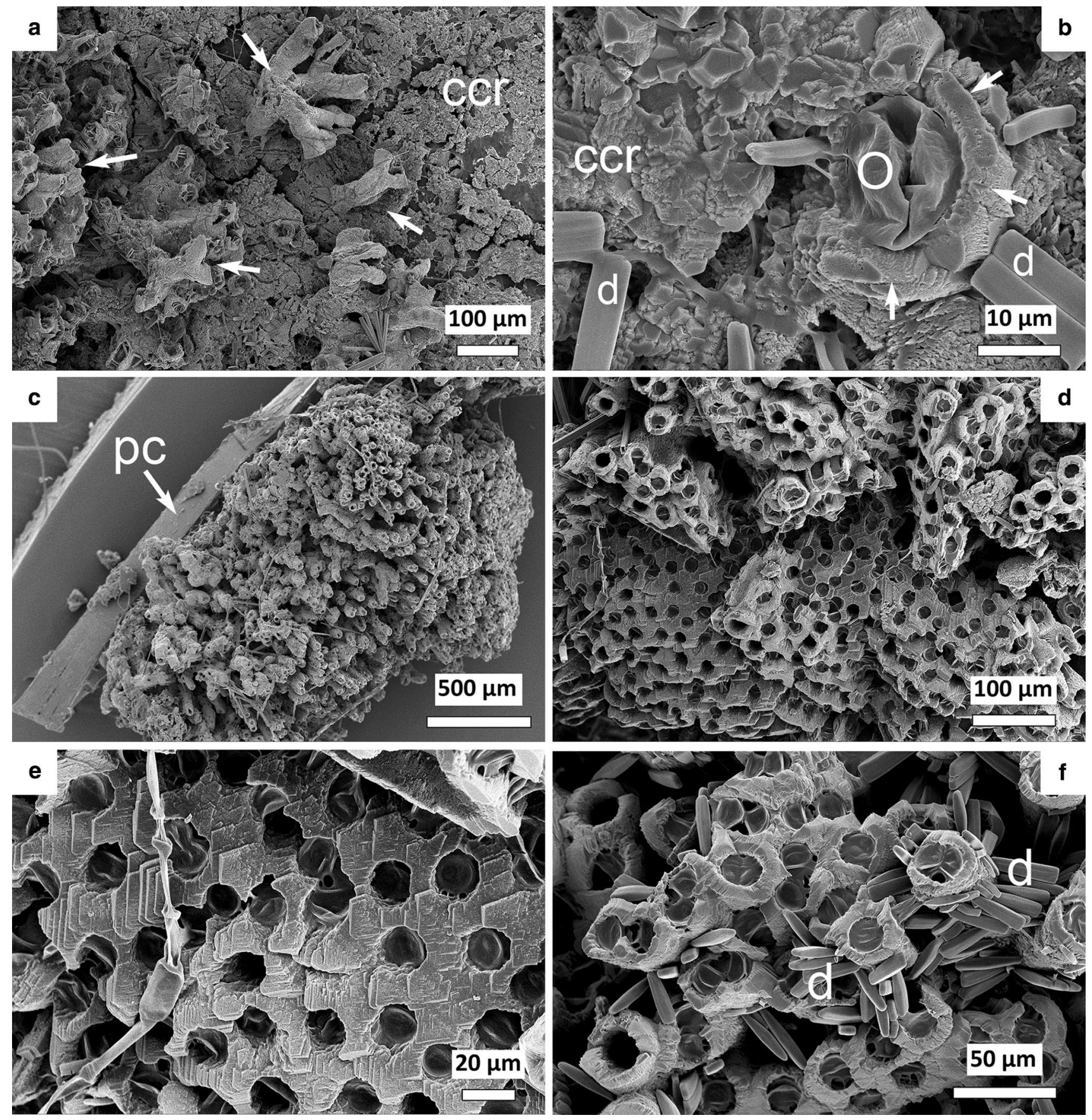

Fig. 9 Oocardium calcites on experimental substrates. a Site 3: Oocardium tubes (arrows) grown from a calcite crust (ccr) precipitated on a plastic strip placed on 11.6.2015; sampled 12.10.2015. b Detail of subfigure a: calcite crust (ccr), and Oocardium cell (O) shortly after settlement. Note diatoms (d) and calcite crystals (arrows)

around the $O$. stratum cell. c Site 3: plastic cord (pc) that waved freely in shooting stream flow and became overgrown by Oocardium calcite. Substrate placed 11.6.2015; sampled 2.11.2015. d, e Details of subfigure c, showing stepped calcification style. f Site 3: green Oocardium calcite associated with diatoms (d) during winter

\section{Discussion}

\section{Viability, calcification, water chemistry}

The persistence of green Oocardium cells over the entire year indicates that the winterly lowering of air temperature

as well as of illumination was not sufficient to extirpate the population. Because the spring stream remained open to the sky even during heavy snowfalls and unfrozen over the observation period (Fig. 5), and because stream temperature varied only up to $3^{\circ}$ (Fig. 4), O. stratum cells bathed within the stream experienced a seasonal change much 

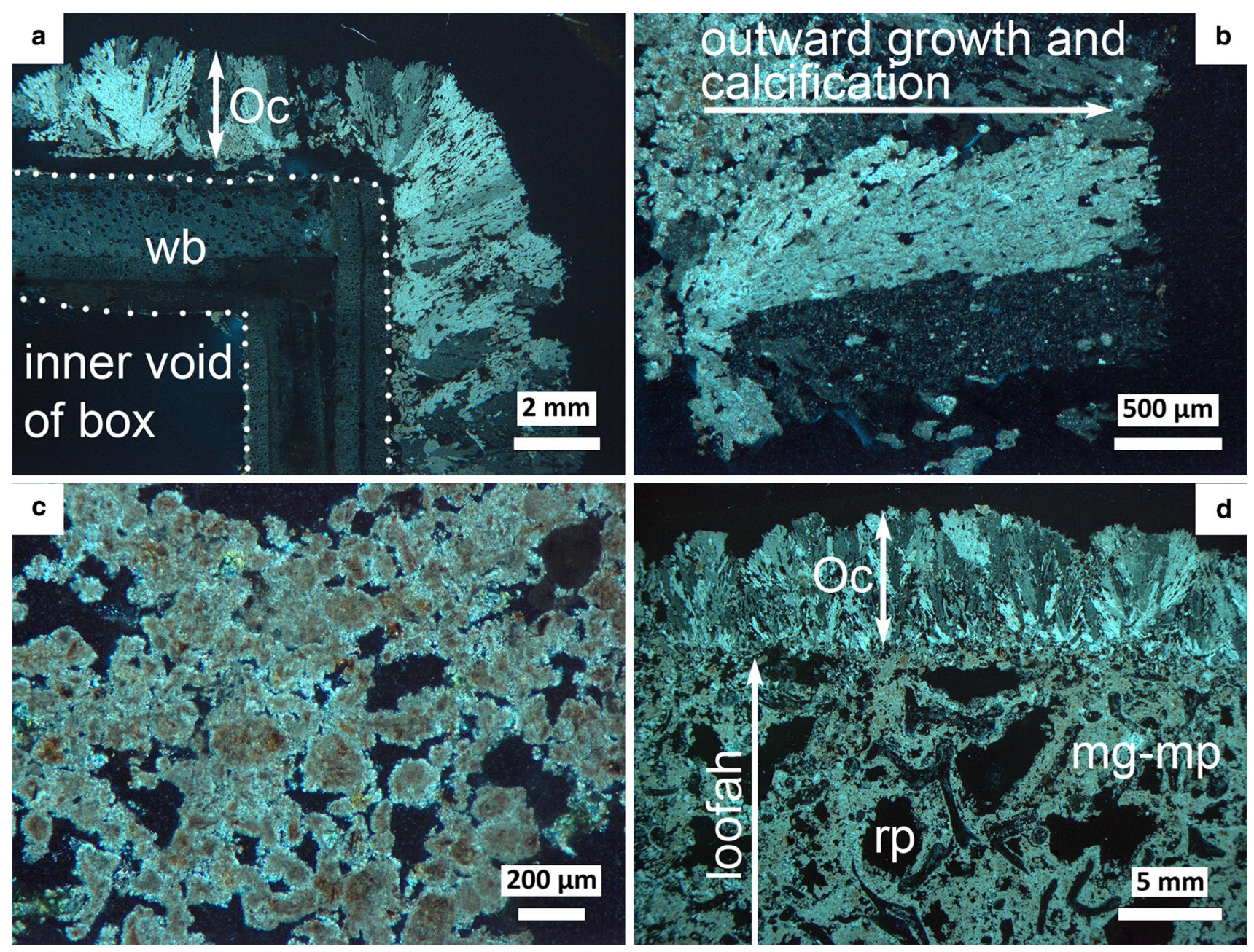

Fig. 10 Oocardium calcites on experimental substrates. a Site 3: thinsection through wooden box (wb) coated by Oocardium calcite (Oc). Crossed nicols. Box placed 17.3.2015; sampled 21.3.2016. b Detail of Oocardium calcite in subfigure a. Crossed nicols. c Micropeloidal grainstone formed in the dark inner void of the wooden box (cf. sub-

figure a). Crossed nicols. d Site 3: thin-section through loofah bathed in the stream. The pore space contains micropeloidal grainstone to packstone $(\mathrm{mg}-\mathrm{mp})$ around remnant pores (rp); the top is coated by Oocardium calcite (Oc). Crossed nicols. Loofah placed 3.2.2015; sampled 21.3.2016

smaller than that of the subaerial environment. O. stratum is documented to thrive over a total temperature range of 4.7-20 ${ }^{\circ} \mathrm{C}$, but most streams wherein it was observed so far are in the range of $8-15^{\circ} \mathrm{C}$ (see Table 5). On the other hand, the spread of green Oocardium cover during spring suggests that an increase in illumination and perhaps also increasing daylength favored cell division and substrate recolonization. Partly comparable results were obtained in earlier studies (in other springs) on seasonal calcification of $O$. stratum: there, Oocardium calcite became overgrown by diatom mats during winter; during spring, the diatoms largely disappeared and/or were outpaced in vertical growth by newly settled calcifying $O$. stratum. In this way, a seasonal lamination of the Oocardium limestone can be produced (Wallner 1933; Sanders and Rott 2009; Linhart and Schagerl 2015). Freezing of stream water, longer snow cover and/or strong seasonal lowering of illumination (e.g., in higher latitudes) may indeed delimit the distribution of $O$. stratum.

From sites 1 to 3, the calcite saturation state was rising, and so did the rate of Oocardium calcification (Fig. 4). The sharp rise of calcification rate from sites 2 to 3, respectively, may indicate optimum conditions for growth and calcification. At site 4, in contrast, highest calcite supersaturation contrasted with a lowered rate of calcification (Fig. 4). The concentrations of $\mathrm{Ca}^{2+}$ and $\mathrm{HCO}_{3}{ }^{-}$at site 4 are well-within the range of concentrations measured at other springs with Oocardium calcification (see Table 5). At site 4, thus, the discrepancy between saturation state and calcification rate may be related to site-specific factors, perhaps (a) intermittently low $\mathrm{CO}_{2}$ concentrations, impeding photosynthetic activity, and/or (b) potential intermittent 

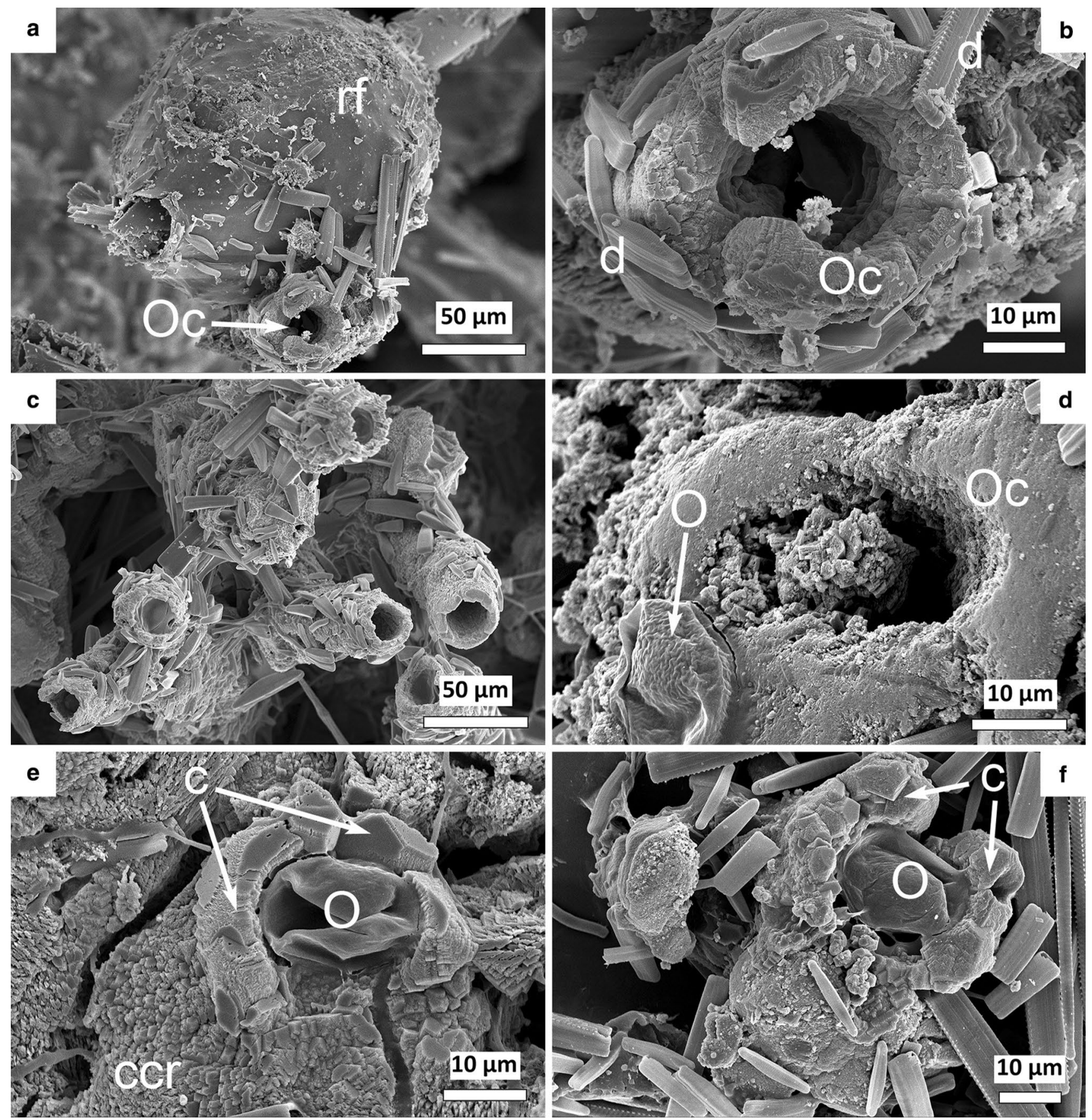

Fig. 11 Colonization and early calcification of $O$. stratum. a Site 4: rinse fleece (rf) overgrown by diatoms and by short tubes of Oocardium calcite (Oc). Substrate placed 3.2.2015; sampled 17.3.2015. b Detail of subfigure a. Abandoned Oocardium calcite (Oc) overgrown by diatoms (d). c Site 4: detail of Oocardium cover grown on rinse fleece during winter 2015-16. Many Oocardium cells remained viable; the calcite tubes were settled by diatoms (d). Substrate placed 3.2.2015; sampled 21.3.2016. d Abandoned Oocardium calcite (Oc),

freezing of the relatively thin water film at site 4 in winter. Culture experiments showed that $O$. stratum consumes only $\mathrm{CO}_{2}$ by passive diffusion and is therefore likely confined and newly settled cell of $O$. stratum $(O)$ still devoid of its housing calcite tube. Sample taken on 30.6.2015. e Site 3: Oocardium cell $(O)$ settled on a calcite crust (ccr). Note calcite crystals (c) around the cell. Substrate placed 11.6.2015; sampled 12.10.2015. f Site 2: early calcification along the edge of a plastic strip. Note ring of calcite crystals (c) around newly settled Oocardium cell. Substrate placed 11.6.2015; sampled 12.10.2015

to (limestone-precipitating) waters of sufficiently high $\mathrm{CO}_{2}$ concentrations and alkalinity (Schagerl and Wukovits 2014). Linhart and Schagerl (2015) suggested that alkalinity and 

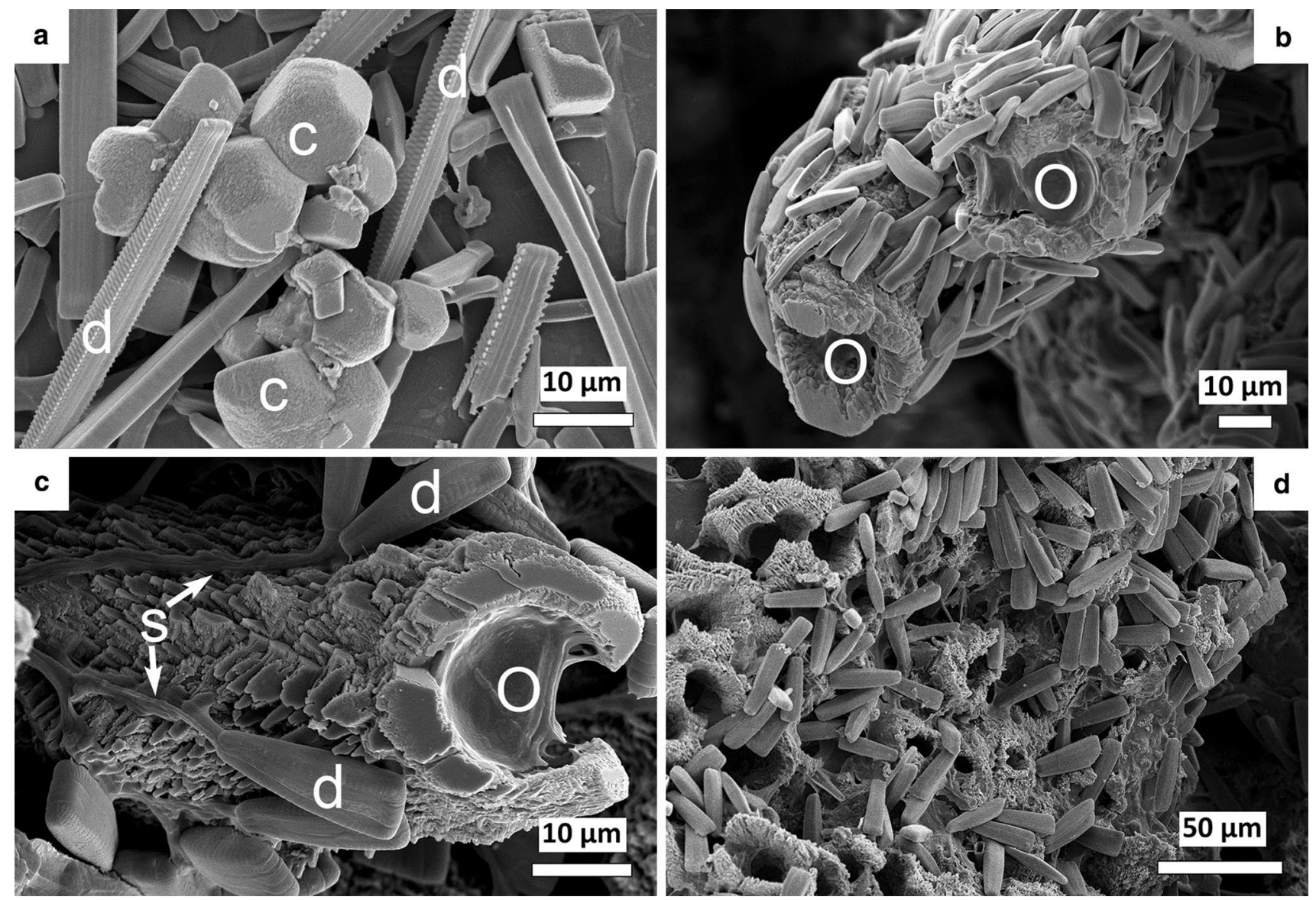

Fig. 12 Diatom colonization of experimental substrates and of Oocardium calcite. a Site 2: diatom colonization of a plastic strip. Note calcite crystals (c) associated with the diatoms (d). Substrate placed 11.6.2015; sampled 2.11.2015. b Diatoms settled on tubes of green Oocardium calcite $(O)$. Sample taken on 21.3.2016. c Diatoms

water temperature are the two most significant controls over $O$. stratum presence and activity, with an alkalinity of $4.7 \mathrm{meq} / \mathrm{l}$ and a temperature of $13{ }^{\circ} \mathrm{C}$ considered as optimal. This might imply that $O$. stratum can persist also in uncalcified form in waters that do not precipitate limestone. Springs of elevated alkalinity but of low $\mathrm{Ca}^{2+}$ concentrations are rare. The $\mathrm{Ca}^{2+}$ concentrations of springs with $O$. stratum spread over two orders of magnitude, but commonly range from a few tens to a few hundreds of $\mathrm{mg} / \mathrm{l}$ (Table 5). So far, O. stratum was observed only in waters of low $\mathrm{Mg}$ / $\mathrm{Ca}$ molar ratio that precipitate low-magnesian calcite, and that are supersaturated for calcite at least along the stream reach with $O$. stratum (Table 5). In view of the fact that $O$. stratum settled only on substrates of calcite and started to induce precipitation of calcite early after settlement (cf. Figs. 8c-e; 9b; 11d, e; see below for further discussion), this strongly suggests that calcification is indispensable. The calcite tubes are required to support the soft mucus stalks of $O$. stratum (cf. Fig. 1a). In absence of calcite precipitation, the (d) grown between tubes of green Oocardium calcite $(O)$. Upon drying, the formerly free-standing diatom stalks (s) adhered to the calcite tube. Sample taken on 30.6.2015. d Diatom mat coating white Oocardium calcite. Sample taken on 28.4.2015

mucus stalks would hardly support upward growth; upon cell division, thus, only sheet-like soft cumulates of $O$. stratum cells were possible. Together, this supports that $O$. stratum requires calcification as an integral part of its life strategy.

At site 1, which showed the highest $\mathrm{CO}_{2}$ concentration (cf. Fig. 4c, Table 2), the practical standstill of Oocardium calcification combined with the lack of substrate colonization together suggest that colonization/calcification was influenced by factors additional to $\mathrm{CO}_{2}$ concentration and alkalinity (e.g., reactive phosphate concentration). The habitat window of $O$. stratum thus may be also framed by a combination of calcite supersaturation with $\mathrm{CO}_{2}$ concentration. As observed on the experimental substrates (flowerpots, plastic strips; Figs. 8c, e, f, 9a, 11e), their surface became coated by a calcite crust that did not show evidence for biological mediation (abiotic calcite), also in SEM. This calcite crust was settled on by $O$. stratum cells. After settlement, the tubes of Oocardium calcite grew upward at a much higher rate than the surrounding abiotic calcite crusts. 
Table 5 Compilation of physico-chemical parameters observed in streams with actively calcifying Oocardium stratum

\begin{tabular}{ll}
\hline Control (unit) & Characterization \\
\hline Water temperature $\left({ }^{\circ} \mathrm{C}\right)$ & $\begin{array}{l}\text { Range: } 4.7-20 \\
\text { Our study: 4.7-15.63 }\end{array}$ \\
& \\
Generalized water chemistry & $\begin{array}{l}\mathrm{Ca}^{2+}-\mathrm{HCO}_{3}^{-}-\left(\mathrm{SO}_{4}{ }^{2-}\right) \text { water; low-magnesian } \\
\text { calcite depositing stream }\end{array}$
\end{tabular}

References, remarks

Electrical conductivity $(\mu \mathrm{S} / \mathrm{cm})$

$\mathrm{pH}$

$\mathrm{CO}_{2}$ concentration $(\mathrm{mg} / \mathrm{l})$

Alkalinity $\left(\mathrm{HCO}_{3}^{-}\right)(\mathrm{mg} / \mathrm{l})$

$\mathrm{Ca}^{2+}$ concentration (mg/l)

Water agitation

$\mathrm{Mg} / \mathrm{Ca}$ molar ratio

Calcite saturation indices (SI)

Sulfate concentration $(\mathrm{mg} / \mathrm{l})$

Nitrate concentration $(\mathrm{mg} / \mathrm{l})$

Total phosphorus concentration (TP) ( $\mu \mathrm{g} / \mathrm{l})$
Range: $0.055-12.69$

Our study: 4.86-7.33

Range: 386.8-906

Our study: 428.67-679.33

Range: $7.1-8.7$

Our study: $7.12-8.7$

Range: $1.44-169.4$

Our study: 3.15-53.14

Range: $176.9-450.3$

Our study: 335-441.75

Range: $1.6-289.2$

Our study: 61.8-99.3

Shallow strongly turbulent flow required. Oocardium prefers streams or stream reaches with high water-air exchange

Range: 0.022-0.706

Our study: 0.46-0.706

0.27-0.81 (calculated from data in Pentecost 1991)

- 0.22 to 1.27 (SI by PHREEQC) (Gradziński 2010)

0.26-1.0 (Langelier SI) (Trobej et al. 2017)

Our study: -0.07 to 1.32 (SI by PHREEQC)

Range: $0.8-745.92$

Our study: $3.6-6.46$

$<15$ (detection limit) to 179.1 , mostly 0.2 to a few micrograms/L

Our study: mostly $<15$; few values 17-21 (summer 2015)
Pentecost (1991), Rüf (2006), Sanders and Rott (2009), Gesierich and Kofler (2010), Gradziński (2010), Rott et al. (2012), Linhart and Schagerl (2015) and Trobej et al. (2017), this study

Oocardium prefers well-lit waters of low-moderate concentration of dissolved major ions (Sanders and Rott 2009)

Rüf (2006), Sanders and Rott (2009), Gesierich and Kofler (2010), Cantonati et al. (2012), Rott et al. (2012), Linhart and Schagerl (2015) and Trobej et al. (2017), this study

Pentecost (1991), Sanders and Rott (2009), Gesierich and Kofler (2010), Gradziński (2010), Rott et al. (2010, 2012), Linhart and Schagerl (2015) and Trobej et al. (2017), this study

Pentecost (1991), Sanders and Rott (2009), Rott et al. (2010, 2012), Linhart and Schagerl (2015) and Trobej et al. (2017), this study

Pentecost (1991), Rüf (2006), Sanders and Rott (2009), Gesierich and Kofler (2010), Gradziński (2010), Rott et al. (2010, 2012), Linhart and Schagerl (2015) and Trobej et al. (2017), this study

Pentecost (1991), Rüf (2006), Sanders and Rott (2009), Rott et al. (2010, 2012), Linhart and Schagerl (2015) and Trobej et al. (2017), this study

Pentecost (1991), Gradziński (2010), Rott et al. (2010) and Linhart and Schagerl (2015), this study

Values calculated from: Pentecost (1991), Rüf (2006), Sanders and Rott (2009), Rott et al. (2012) and Trobej et al. (2017), this study

Pentecost (1991), Gradziński (2010) and Trobej et al. (2017), this study

Pentecost (1991), Rüf (2006), Sanders and Rott (2009), Gesierich and Kofler (2010), Cantonati et al. (2012), Rott et al. (2012), Linhart and Schagerl (2015) and Trobej et al. (2017), this study

Pentecost (1991), Rüf (2006), Gesierich and Kofler (2010), Cantonati et al. (2012), Rott et al. (2012), Linhart and Schagerl (2015) and Trobej et al. (2017), this study

Pentecost (1991), Gesierich and Kofler (2010), Rott et al. (2012), Linhart and Schagerl (2015) and Trobej et al. (2017), this study 
Under conditions of overall supersaturation, $O$. stratum thus accelerated calcite precipitation. $O$. stratum seems to be resilient against a wide range of sulfate and nitrate concentrations, i.e., over at least three orders (sulfate) and two orders of magnitude (nitrate) (see Table 5). In our study, the total phosphorus concentration in most cases was below the detection limit of $0.015 \mathrm{mg} / \mathrm{l}$; only during summer 2015 , a few values of up to $0.021 \mathrm{mg} / \mathrm{l}$ were determined (Table 2). The nitrate and phosphorus concentrations of our study and of former studies suggest that $O$. stratum prefers oligotrophic to ultraoligotrophic waters (cf. Rott et al. 2012).

\section{Initial calcification style and cell arrangement}

As described, the downstream range of initial calcification styles on the growing tips of the Oocardium calcite tubes was similar both on the natural stream bed and on experimental substrates. The downstream change of initial crystal fabrics and rates of precipitation, from (i) crystal-skeletal fabrics at site 1 (lowest calcite supersaturation, practically no precipitation; cf. Fig. 6a-d) to (ii) massive-idiomorphic fabrics at sites 3 and 4 (highest supersaturation, high precipitation; cf. Figs. 7e, 8b) contrasts with conventional correlations of crystal habit with degree of oversaturation. Whereas crystal skeletons form rapidly at high degrees of supersaturation, idiomorphic crystals precipitate slowly at low supersaturation (e.g., Sunagawa 2005); the physical explanation for this is that at high supersaturation, rapid crystallization proceeds along the energetically most favorable planes (intersections of main crystal surfaces) and lines (e.g., crystallographic c-axis); at low supersaturation and slow crystal growth, in contrast, there is time to occupy also the energetically less favorable inner parts of crystal surfaces, to result in an idiomorphic crystal (Sunagawa 2005).

Induced calcification in ambient-temperature spring streams, however, is different in that over a comparatively narrow range of temperature the degree of supersaturation is strongly controlled by $\mathrm{CO}_{2}$ concentration (cf. Chen et al. 2004). The crystal-skeletal fabrics at site 1 (highest $\mathrm{CO}_{2}$ concentration) thus suggest that supersaturation at the site of crystallization is too low to allow for occupation also of the energetically less favorable crystal surfaces. Dissolution of calcite can result in a 'spiky' surface (e.g., Jones and Pemberton 1987) and similar surface fabrics were produced by experimental etching of Oocardium calcite (Pentecost 1991). Spiky surface produced by calcite dissolution, however, differs in appearance from the crystalskeletal fabric observed at site 1 . Moreover, if the crystal-skeletal fabric resulted from dissolution, both active degradation of the calcite that formed within the EPS of the diatom-bacterial films on the experimental substrates and degradation of the natural Oocardium calcite at site 1 should be expected. No clear-cut evidence was seen for active calcite dissolution. Furthermore, the arrangement of cells on the natural Oocardium calcite at site 1 into clusters and rows supports the hypothesis that the crystalskeletal fabric is of primary instead of a secondary origin. The crystal-skeletal fabrics at site 1 thus seemed to result from limitation, not rapidity, of crystallization. Conversely, the massive-idiomorphic calcite fabrics at sites 3 and 4 suggest that supersaturation was sufficiently high to allow for full crystallization. The crystal-skeletal fabrics of site 1 also fundamentally differed from travertine calcite precipitated from hot springs. In hot springs, whisker crystals and diverse forms of dendritic-skeletal crystals mainly result from rapid, significant cooling combined with rapid $\mathrm{CO}_{2}$ loss upon depressurization (Guo and Riding 1998; Jones and Renaut 2008; Jones and Peng 2012; Jones 2017). The crystal whiskers to dendrites to skeletons formed at hot springs seem to largely correspond to the conventional interpretation of crystallization fabrics (cf. Sunagawa 2005).

The style of cell arrangements of $O$. stratum also appears to correspond with calcite supersaturation and precipitation rate; at site 1, the most distinct clustered cell arrangements are positioned between widely and spaced calcite "pillars" with crystal-skeletal fabric (cf. Fig. 2b, c); at site 2, cell rows are common aside of single-celled tubes (Fig. 2d). Farther downstream, at sites 3 and 4, only single-celled calcite tubes were found (cf. Figs. 1a, c, d, g; 2a). The differences in cell arrangements may be interpreted as a reaction to degree of calcite supersaturation: under low supersaturation (site 1), it is hardly possible for a cell to precipitate a tube on its own; upon division, thus, cells become positioned in a cluster adjacent to each other. Under higher supersaturation, in contrast, each cell can induce the precipitation of its own calcite tube. Comparison to previous studies suggests that the described variations of cell arrangement, in particular, the clusters and rows, are relatively rare or had not been taken care of in documentation. In any case, the single-celled housing seems to be the most widespread. In as much the relatively low calcite supersaturation at site 1 is the prime factor or an important factor at least, for the lack of active substrate colonization by $O$. stratum cannot be assessed with the data at hand.

\section{Oocardium ecology and calcification}

On precipitation substrates with a large pore space (e.g., rinse fleece, loofah, boxes of balsa wood; Table 3) the low-lit or dark pore space became filled mainly by micropeloidal grainstone to packstone. Conversely, the day-lit outer surfaces were colonized by diatoms and Oocardium. A similar fabric development is observed in natural spring limestones (cf. Sanders and Rott 2009). The observation that $O$. stratum directly settled on calcite suggests that it requires calcite for settlement, be it a large single crystal or clusters of small crystals such as those 
formed in bacterial-diatom biofilms that 'prepare the ground' for settlement (cf. Figs. 6e, f; 11a).

Fallen leaves (Fig. 5e) quench biocalcification beneath them while their upper side is recolonized by $O$. stratum, mainly along their margins and protruding leave nerves (Fig. 5f). This 'edge effect' of colonization is probably related to microhabitat conditions, perhaps submillimeter-scale water turbulence facilitating $\mathrm{CO}_{2}$ uptake (cf. Chen et al. 2004). The seasonal input of leaves might help to support the long-term stability of the diatom/O. stratum assemblage, mainly because diatoms and $O$. stratum are effective colonizers, and because a cover of Oocardium calcite may be difficult to invade by cyanobacteria and mosses (cf. Linhart and Schagerl, 2015). Moss tufts may be so densely colonized by calcifying $O$. stratum to become ultimately choked (Rüf 2006; Sanders et al. 2006; Willegger 2008; Sanders and Rott 2009). Several factors thus may combine to keep stream beds open for $O$. stratum, (1) its capability for effective colonization and rapid calcification, and (2) partial cover with fallen leaves that are quickly re-colonized.

The rate of $O$. stratum calcification increased downstream, from zero at site 1 to a maximum at site 3 . At site 3 , the mean calcification rate of $370 \mu \mathrm{m} /$ month and the maximum rate of $500 \mu \mathrm{m} /$ month rank intermediate relative to rates reported from other springs (cf. West et al. 1923; Sanders and Rott 2009; Linhart and Schagerl 2015). The highest rate of upward growth of Oocardium calcite observed so far amounts to $830 \mu \mathrm{m} /$ month (or $10 \mathrm{~mm} / \mathrm{a}$, Sanders and Rott 2009). As a result of seasonal changes in calcification, spring limestones composed of Oocardium calcite consist of laminae typically between 3 and $8 \mathrm{~mm}$ in thickness (cf. Sanders and Rott 2009; Ibarra et al. 2014).

\section{Conclusions}

1. The vertical calcification of Oocardium stratum proceeded at a maximum rate of $500 \mu \mathrm{m} / \mathrm{month}$, which is within the range of rates documented previously from other springs.

2. Oocardium stratum remained viable and colonized new substrates also during winter. Calcitic substrates were colonized by single Oocardium cells that, after settling, induced precipitation of calcite crystals around themselves; then, a mucus stalk was secreted that supported upward growth of the microalga within a housing tube of calcite. Non-calcitic substrates, in turn, were first colonized by biofilms of unspecified bacteria and diatoms. Calcite crystal aggregates formed within these biofilms later provided the substrate for $O$. stratum settlement. The crucial role of biofilms of diatoms and/or bacteria in 'preparing the ground' for Oocardium to colonize noncalcitic substrates was identified for the first time.
3. At low calcite supersaturation and relatively high $\mathrm{CO}_{2}$ concentration (upstream), O. stratum cells formed atypical clusters and rows between 'pillars' or 'walls' of Oocardium calcite with a crystal-skeletal fabric. At higher supersaturation and lower $\mathrm{CO}_{2}$ concentration (downstream), rhombohedral calcite initially formed along the tips of upward growing calcite tubes, each housed by a single $O$. stratum cell, as described in previous studies.

4. Because Oocardium calcite provides a highly differentiated substrate for settlement, diatoms benefit from being associated with $O$. stratum. Conversely, because of their photosynthesis, at least dense diatom populations settled on Oocardium calcite perhaps aid to increase local calcite supersaturation. In general, the role of diatoms in total spring calcification is under-investigated and requires further study.

5. The niche of $O$. stratum can be characterized as: Perennial, ambient-temperature streams with low to moderately mineralized $\mathrm{Ca}-(\mathrm{Mg})-\mathrm{HCO}_{3}-\left(\mathrm{SO}_{4}\right)$ water; total phosphorus is low to very low (oligotrophic-ultraoligotrophic; typically $<15$ to $21 \mu \mathrm{g} / \mathrm{l})$, nitrate concentrations $(0.055-$ $12.69 \mathrm{mg} / \mathrm{l})$ and sulfate concentrations $(0.8-745.92 \mathrm{mg} / \mathrm{l})$ can be highly variable. The stream bed-in most cases of Oocardium calcite-is characterized by shallow, highly turbulent flow. This conclusion is based on the results of the present study and of previously published articles.

6. Fossil deposits of freshwater limestones previously thought to be entirely or largely of cyanobacterial origin may contain a hitherto unidentified "eukaryotic component", or in some cases may even have been largely produced by eukaryotic calcifiers.

Acknowledgements Open access funding provided by University of Innsbruck and Medical University of Innsbruck. This paper is part of the Ph.D. thesis of Ha Tran, carried out at the Institute of Geology of the University of Innsbruck. Financial support from student exchange Project 911 of the OeAD Vietnam-Austria Ph.D. Scholarship Programme and Nachwuchsförderung der Universität Innsbruck are gratefully acknowledged. The comments of Allan Pentecost, an anonymous reviewer, and of the editor Wolfgang Kiessling helped to improve the quality of presentation.

Open Access This article is distributed under the terms of the Creative Commons Attribution 4.0 International License (http://creativeco mmons.org/licenses/by/4.0/), which permits unrestricted use, distribution, and reproduction in any medium, provided you give appropriate credit to the original author(s) and the source, provide a link to the Creative Commons license, and indicate if changes were made.

\section{References}

Arp G, Reimer A, Reitner J (2001) Photosynthesis-induced biofilm calcification and calcium concentrations in Phanerozoic oceans. 
Science 292(5522):1701-1704. https://doi.org/10.1126/scien ce. 1057204

Ausserlechner R (2012) Die Quellkalke von Mariastein (Tirol) (Bachelor thesis). University of Innsbruck, Innsbruck, p 42

Blank CE (2013) Origin and early evolution of photosynthetic eukaryotes in freshwater environments: reinterpreting Proterozoic paleobiology and biogeochemical processes in light of trait evolution. $\mathrm{J}$ Phycol 49(6):1040-1055. https://doi.org/10.1111/jpy.12111

Cantonati M, Rott E, Spitale D, Angeli N, Komárek J (2012) Are benthic algae related to spring types? Freshw Sci 31(2):481-498. https://doi.org/10.1899/11-048.1

Cantonati M, Segadelli S, Ogata K, Tran H, Sanders D, Gerecke R, Rott E, Filippini M, Gargini A, Celico F (2016) A global review on ambient-temperature limestone-precipitating spring (LPS): hydrogeological setting, ecology, and conservation. Sci Total Environ 568:624-637. https://doi.org/10.1016/j.scitotenv.2016.02.105

Charlton SR, Parkhurst DL (2002) PHREEQCI-a graphical user interface to the geochemical model PHREEQC (report 031-02). Colorado USA, US Geological Survey, p 2

Charlton SR, Parkhurst DL (2011) Modules based on the geochemical model PHREEQC for use in scripting and programming languages. Comput Geosci 37(10):1653-1663. https://doi. org/10.1016/j.cageo.2011.02.005

Chen J, Zhang DD, Wang S, Xiao T, Huang R (2004) Factors controlling tufa deposition in natural waters at waterfall sites. Sed Geol 166(3-4):353-366. https://doi.org/10.1016/j.sedgeo.2004.02.003

Erba E (2006) The first 150 million years history of calcareous nannoplankton: biosphere-geosphere interactions. Palaeogeogr Palaeoclimatol Palaeoecol 232(2):237-250. https://doi.org/10.1016/j. palaeo.2005.09.013

Folk RL (1974) The natural history of crystalline calcium carbonate: effect of magnesium content and salinity. J Sediment Petrol 44(1):40-53. https://doi.org/10.1306/74D72973-2B2111D7-8648000102C1865D

Gattuso JP, Frankignoulle M, Bourge I, Romaine S, Buddemeier RW (1998) Effect of calcium carbonate saturation of seawater on coral calcification. Glob Planet Change 18(1):37-46. https://doi. org/10.1016/S0921-8181(98)00035-6

Gerdes G, Krumbein WE (1987) Biolaminated deposits. In: Bhattacharji S, Friedman GM, Neugebauer HJ, Seilacher A (eds) Lecture notes in earth sciences, vol 9. Springer, Berlin, p 183. https://doi. org/10.1007/BFb0021878

Gesierich D, Kofler W (2010) Are algal communities from near-natural rheocrene springs in the Eastern Alps (Vorarlberg, Austria) useful ecological indicators? Algol Stud 133(1):1-28. https://doi. org/10.1127/1864-1318/2010/0133-0001

Gontcharov AA, Marin B, Melkonian M (2003) Molecular phylogeny of conjugating green algae (Zygnemophyceae, Streptophyta) inferred from SSU rDNA sequence comparisons. J Mol Evol 56(1):89-104. https://doi.org/10.1007/s00239-002-2383-4

Gradziński M (2010) Factors controlling growth of modern tufa: results of a field experiment. Geol Soc Lond Spec Publ 336(1):143-191. https://doi.org/10.1144/sp336.8

Granier B (2012) The contribution of calcareous green algae to the production of limestones: a review. Geodiversitas 34(1):35-60. https://doi.org/10.5252/g2012n1a3

Grüninger W, Günzl H (2018) Neu entdeckte vorkommen der zieralge Oocardium stratum nägeli, $1849 \mathrm{im}$ tobel der wolfegger Ach im oberschwäbischen alpenvorland. Jahresh Ges Naturkd Württ 174:11-26

Guo L, Riding R (1998) Hot-spring travertine facies and sequences, Late Pleistocene, Rapolano Terme, Italy. Sedimentology 45(1):163-180. https://doi.org/10.1046/j.1365-3091.1998.00141.x

Gutner-Hoch E, Waldman Ben-Asher H, Yam R, Shemesh A, Levy O (2017) Identifying genes and regulatory pathways associated with the scleractinian coral calcification process. PeerJ 5:e3590. https ://doi.org/10.7717/peerj.3590

Ibarra Y, Corsetti FA, Cheetham MI, Feakins SJ (2014) Were fossil spring-associated carbonates near Zaca Lake, Santa Barbara, California deposited under an ambient or thermal regime? Sed Geol 301:15-25. https://doi.org/10.1016/j.sedgeo.2013.12.005

Jackson D, Macis L, Reitner J, Wörheide G (2011) A horizontal gene transfer supported the evolution of an early metazoan biomineralization strategy. BMC Evol Biol 11(1):238. https://doi. org/10.1186/1471-2148-11-238

Jones B (2017) Review of calcium carbonate polymorph precipitation in spring systems. Sed Geol 353:64-75. https://doi.org/10.1016/j. sedgeo.2017.03.006

Jones B, Pemberton SG (1987) Experimental formation of spiky calcite through organically mediated dissolution. J Sed Petrol 57:687-694

Jones B, Peng X (2012) Amorphous calcium carbonate associated with biofilms in hot spring deposits. Sed Geol 269-270:58-68. https:// doi.org/10.1016/j.sedgeo.2012.05.019

Jones B, Renaut RW (2008) Cyclic development of large, complex, calcite dendrite crystals in the Clinton travertine, Interior British Columbia, Canada. Sed Geol 203(1-2):17-35. https://doi. org/10.1016/j.sedgeo.2007.10.002

Jones B, Renaut RW (2010) Calcareous spring deposits in continental settings. In: Alonso-Zarza AM, Tanner LH (eds) Developments in sedimentology, vol 61. Elsevier, Amsterdam, pp 177-224. https:// doi.org/10.1016/S0070-4571(09)06104-4

Kawaguchi T, Decho AW (2002) A laboratory investigation of cyanobacterial extracellular polymeric secretions (EPS) in influencing $\mathrm{CaCO}_{3}$ polymorphism. J Cryst Growth 240(1):230-235. https:// doi.org/10.1016/S0022-0248(02)00918-1

Konhauser KO (2007) Introduction to geomicrobiology. Blackwell Publishing, Oxford, $\mathrm{p} 425$

Linhart C, Schagerl M (2015) Seasonal calcification of the travertineforming desmid Oocardium stratum. J Phycol 51(6):10551065. https://doi.org/10.1111/jpy.12345

McConnaughey TA, Whelan JF (1997) Calcification generates protons for nutrient and bicarbonate uptake. Earth Sci Rev 42(1-2):95177. https://doi.org/10.1016/S0012-8252(96)00036-0

Merz MUE (1992) The biology of carbonate precipitation by cyanobacteria. Facies 26(1):81-101. https://doi.org/10.1007/BF02539795

Parkhurst DL, Appelo CAJ (1999) User's guide to PHREEQC (version 2): a computer program for speciation, batch-reaction, onedimensional transport, and inverse geochemical calculations (water-resources investigations report 99-4259). Geological Survey, Colorado USA, p 312

Pentecost A (1991) A new and interesting site for the calcite-encrusted desmid Oocardium stratum Naeg. In the British Isles. Br Phycol J 26(4):297-301. https://doi.org/10.1080/00071619100650261

Pentecost A (2005) Travertine. Springer, Berlin, p 445

Perfler L, Kahlenberg V, Wikete C, Schmidmair D, Tribus M, Kaindl R (2015) Nanoindentation, high-temperature behavior, and crystallographic/spectroscopic characterization of the high-refractiveindex materials $\mathrm{TiTa}_{2} \mathrm{O}_{7}$ and $\mathrm{TiNb}_{2} \mathrm{O}_{7}$. Inorg Chem 54(14):68366848. https://doi.org/10.1021/acs.inorgchem.5b00733

Perfler L, Kahlenberg V, Többens D, Schaur A, Tribus M, Orlova M, Kaindl R (2016) Mechanical properties, quantum mechanical calculations, and crystallographic/spectroscopic characterization of $\mathrm{GaNbO} 4, \mathrm{Ga}(\mathrm{Ta}, \mathrm{Nb}) \mathrm{O} 4$, and $\mathrm{GaTaO} 4$. Inorg Chem 55(11):5384-5397. https://doi.org/10.1021/acs.inorg chem.6b00386

Pfiester OPLA (1976) Oocardium stratum a rare (?) desmid (Chlorophyceae). J Phycol 12(1):134. https://doi. org/10.1111/j.1529-8817.1976.tb02841.x

Pomar L, Hallock P (2008) Carbonate factories: a conundrum in sedimentary geology. Earth Sci Rev 87(3):134-169. https://doi. org/10.1016/j.earscirev.2007.12.002 
Pratt BR (2001) Calcification of cyanobacterial filaments: Girvanella and the origin of lower Paleozoic lime mud. Geology 29(9):763766. https://doi.org/10.1130/0091-7613(2001)029\%3c076 3:COCFGA\%3e2.0.CO;2

Riding R (1992) Temporal variation in calcification in marine cyanobacteria. J Geol Soc 149(6):979-989. https://doi.org/10.1144/ gsjgs.149.6.0979

Riding R (2011) Calcified cyanobacteria. In: Reitner J, Thiel V (eds) Encyclopedia of geobiology. Encyclopedia of earth sciences series. Springer, Dordrecht, pp 211-223. https://doi. org/10.1007/978-1-4020-9212-1_63

Ries JB (2009) Review: the effects of secular variation in seawater Mg/ $\mathrm{Ca}$ on marine biocalcification. Biogeosci Discuss 6:7325-7452 (Copernicus Publications on behalf of the European Geosciences Union)

Rott E, Holzinger A, Gesierich D, Kofler W, Sanders D (2010) Cell morphology, ultrastructure and calcification pattern of Oocardium stratum, a peculiar lotic desmid. Protoplasma 243(1-4):39-50. https://doi.org/10.1007/s00709-009-0050-y

Rott E, Hotzy R, Cantonati M, Sanders D (2012) Calcification types of Oocardium stratum Nägeli and microhabitat conditions in springs of the Alps. Freshw Sci 31(2):610-624. https://doi. org/10.1899/11.084.1

Rüf B (2006) Quelltuff in vorarlberg-sedimentologische, materialkundliche und bauhistorische Aspekte (diploma thesis). University of Innsbruck, Innsbruck, p 173 (with appendix, p 49; 1 map)

Sanders D, Rott E (2009) Contrasting styles of calcification by the micro-alga Oocardium stratum NAEGELI 1849 (zygnematophyceae) in two limestone-precipitating spring creeks of the Alps. Austrian Journal of Earth Sciences 102:34-49

Sanders D, Unterwurzacher M, Rüf B (2006) Microbially induced calcium carbonate in tufas of the western Eastern Alps: a first overview. GeoAlp 3:167-189

Sanders D, Wertl W, Rott E (2011) Spring-associated limestones of the Eastern Alps: overview of facies, deposystems, minerals and biota. Facies 57(3):395-416. https://doi.org/10.1007/s1034 7-010-0252-y

Schagerl M, Wukovits J (2014) Cultivation and inorganic carbon uptake of the rare desmid Oocardium stratum (Conjugatophyceae). Phycologia 53(4):320-328. https://doi.org/10.2216/13-228.1
Stanley SM, Ries JB, Hardie LA (2002) Low-magnesium calcite produced by coralline algae in seawater of Late Cretaceous composition. Proc Natl Acad Sci 99(24):15323-15326. https://doi. org/10.1073/pnas.232569499

Starnberger R, Drescher-Schneider R, Reitner JM, Rodnight H, Reimer P, Spötl C (2013) Late Pleistocene climate change and landscape dynamics in the Eastern Alps: the inner-Alpine Unterangerberg record (Austria). Quatern Sci Rev 68:17-42. https://doi. org/10.1016/j.quascirev.2013.02.008

Strother PK, Battison L, Brasier MD, Wellman CH (2011) Earth's earliest non-marine eukaryotes. Nature 473:505-509. https://doi. org/10.1038/nature09943

Sunagawa I (2005) Crystals: growth, morphology and perfection. Cambridge University Press, Cambridge, p 295

Trobej M, Bednar JP, Waringer J, Schagerl M (2017) Algal communities of spring-associated limestone habitats. Aquat Microb Ecol 80:61-75. https://doi.org/10.3354/ame01836

Wallner J (1933) Oocardium stratum naeg., eine wichtige tuffbildende Alge südbayerns. Planta 20(2):287-293. https://doi.org/10.1007/ BF01909569

Wallner J (1934a) Über die Beteiligung kalkablagernder pflanzen bei der bildung südbayerischer tuffe. Bibl Bot 110:1-30

Wallner J (1934b) Über die verbreitungsökologie des desmidiacee Oocardium. Planta 23:249-263. https://doi.org/10.1007/BF019 25450

Wallner J (1935) Zur kenntnis der gattung oocardium. Hedwigia 75:130-136

Wellman CH, Strother PK (2015) The terrestrial biota prior to the origin of land plants (embryophytes): a review of the evidence. Palaeontology 58(4):601-627. https://doi.org/10.1111/pala.12172

West W, West GS, Carter N (1923) A monograph of the British Desmidiaceae, 5. Ray Soc Monogr 108:1-300

Willegger C (2008) Biokalzifikation der grünalge Oocardium stratum (bachelor thesis). University of Innsbruck, Innsbruck, p 39

Wood R, Ivantsov AY, Zhuravlev AY (2017) First macrobiota mineralization was environmentally triggered. Proc R Soc B 284:20170059. https://doi.org/10.1098/rspb.2017.0059 